Mislav Gabelica

\title{
MLADOHRVATSKI POKRET DO ODVAJANJA OD STARČEVIĆEVE HRVATSKE STRANKE PRAVA 1910. GODINE
}

Mislav Gabelica

Institut društvenih znanosti Ivo Pilar Zagreb

\author{
UDK [323.23+329.78] $(497.5)^{\prime \prime} 18 / 19^{\prime \prime}$ \\ $329(497.5)^{\prime \prime} 18 / 19^{\prime \prime}$ \\ Izvorni znanstveni rad \\ Primljeno: 18.6.2014. \\ Prihvaćeno: 14.12.2016. \\ DOI: http://doi.org/10.21857/ypn4oc6r89
}

Autor se u ovom radu, temeljenom na analizi izvorne građe, tekstova iz onovremenih publikacija, brošura i memoara, bavi genezom mladohrvatskog pokreta, te analizom njegove strukture, značenja i djelovanja u prvoj fazi njegovog postojanja, odnosno do njegovog odvajanja od Starčevićeve hrvatske stranke prava 1910. godine, u čijem se okviru do tada razvijao. Osnovna je teza ovoga rada da je suština mladohrvatskog pokreta, kao i ostalih omladinskih pokreta koji su se u to vrijeme javili u Hrvatskoj, bila politizacija srednjoškolske mladeži, kako bi ju se već u toj dobi vezalo uz određene političke programe.

Ključne riječi: Starčevićeva hrvatska stranka prava, studenti, srednjoškolci, mladohrvatski pokret

\section{Uvod}

Ovaj se rad bavi genezom mladohrvatskog pokreta, te analizom njegove strukture, značenja i djelovanja u prvoj fazi njegovog postojanja, odnosno do 1910. godine i njegovog odvajanja od Starčevićeve hrvatske stranke prava, u čijem se okviru do tada razvijao. Dosadašnja historiografija ovom se temom bavila u sklopu širih ili srodih tema. ${ }^{1}$ Mada je nedvojbena činjenica da se mladohrvatski pokret razvio u krilu

\footnotetext{
Mirjana Gross, Studentski pokret 1875.-1914., Spomenica u povodu proslave 300-godišnjice Sveučilišta u Zagrebu, knjiga 1, Zagreb 1969., str. 451-479; Mirjana Gross, Nacionalne ideje studentske omladine u Hrvatskoj uoči I. svjetskog rata, Historijski zbornik, sv. 21-22, Zagreb 1969., str. 75-142; Tihana Luetić, Hrvatsko akademsko potporno društvo (1894.-1914.), Zbornik Odsjeka za povijesne znanosti Zavoda za povijesne i društvene znanosti Hrvatske akademije znanosti i umjetnosti, sv. 29, Zagreb 2011., str. 311-332; Stjepan Matković, Josip Matasović i "mladohrvatski” pokret, u: Josip Matasović i paradigma kulturne povijesti, ur. Suzana Leček, Slavonski Brod - Zagreb 2013., str. 151-163; Mato Artuković, Politički nazori
} 
Mislav Gabelica: Mladohrvatski pokret do odvajanja od Starčevićeve hrvatske stranke prava... Zb. Odsjeka povij. znan. Zavoda povij. druš. znan. Hrvat. akad. znan. umjet., 34 (2016), str. 213-238

Starčevićeve hrvatske stranke prava, u historiografiji prevladava mišljenje da je njegovo osnovno obilježje odvajanje njegovih sudionika od te stranke i traženje vlastitog političkog puta. Međutim, kako je do tog odvajanja u potpunosti došlo tek 1910. godine, ovim se mišljenjem zapostavlja početna faza mladohrvatskog pokreta, u kojoj se nalazi i razlog njegovog nastanka. Drugim riječima, mladohrvatski pokret nije nastao zbog toga da bi se odvojio od Starčevićeve hrvatske stranke prava, nego zbog drugog razloga. Prema mome mišljenju, što je i osnovna teza ovoga članka, suštinu svih omladinskih pokreta u Hrvatskoj početkom 20. stoljeća, a time i suštinu mladohrvatskog pokreta, valja tražiti u politizaciji srednjoškolske mladeži, kako bi se ta mladež, već u toj dobi, vezala uz određene političke programe.

Navedena tema ovoga članka obrađena je na temelju dosadašnjih historiografskih spoznaja te na temelju analize izvorne građe, brošura, memoara i osobito tekstova iz onodobnih srednjoškolsko-studentskih i stranačkih publikacija: Mlade Hrvatske, Hrvatskog djaka, Luči, Grabancijaša, Hrvatskoga prava i Hrvatske slobode. Pritom su pojedine cjeline unutar ove teme određene kronološkim načelom, te redom obrađuju odnos snaga na zagrebačkom Sveučilištu do pojave mladohrvatskog pokreta, pojavu suparničkih omladinskih pokreta, pojavu mladohrvatskog pokreta i njegovo djelovanje $\mathrm{u}$ prvim godinama njegova postojanja i naposljetku stanje toga pokreta $\mathrm{u}$ trenutku njegovog odvajanja od svoje matične političke stranke, odnosno Starčevićeve hrvatske stranke prava.

\section{Pravaška mladež na Sveučilištu u Zagrebu do početka 20. stoljeća}

Od osamdesetih godina 19. stoljeća, među studentima Sveučilišta u Zagrebu dominirala je pravaška mladež. ${ }^{2}$ Manji dio studenata pripadao je mladeži Neodvisne narodne stranke. Ta će mladež postati jezgrom Napredne omladine, ${ }^{3}$ koja se na Sveučilištu u Zagrebu pojavila 1896. godine. ${ }^{4}$ Nakon raskola u Stranci prava, 1895. godine, veći dio pravaške mladeži priklonio se Čistoj stranci prava, ${ }^{5}$ tzv. frankovcima, kojoj se nakon smrti Ante Starčevića na čelu našao Josip Frank, dok je manji dio pristao uz maticu Stranke prava, tzv. domovinaše. Od tada pa do početka 20. stoljeća, studentska mladež koja je pristajala uz Čistu stranku prava dominirala je Sveučilištem u Zagrebu. ${ }^{6}$ Nakon toga slijedila je gotovo desetogodišnja dominacija

Josipa Matasovića, u: Josip Matasović i paradigma kulturne povijesti, str. 165-204. O mladohrvatskom pokretu u njegovoj kasnijoj fazi, nakon njegovog odvajanja od Starčevićeve hrvatske stranke prava, vidi: Mislav Gabelica, Pravaška mladež na hrvatskom sveučilištu uoči Prvoga svjetskog rata, Društvena istraživanja, god. 20, br. 4 (114.), Zagreb 2011., str. 1139-1161. Vidi i: Vice Zaninović, Mlada Hrvatska uoči I svjetskog rata, Historijski zbornik, sv. 11-12, Zagreb 1958.-1959., str. 65-104, u kojem autor Mladom Hrvatskom, po uzoru na Mladu Bosnu, naziva uglavnom jugoslavensko-nacionalističku omladinu u Hrvatskoj neposredno uoči Prvoga svjetskog rata.

2 Mirjana Gross, Studentski pokret 1875.-1914., u: Spomenica u povodu proslave 300-godišnjice, str. 455.

3 Ivan Peršić, Kroničarski spisi, prir. Stjepan Matković, Zagreb 2002., str. 147-148.

4 Tihana Luetić, Studenti Sveučilišta u Zagrebu (1874.-1914.). Društveni život, svakodnevica, kultura, politika, Zagreb 2012., str. 377.

5 Gross, Nacionalne ideje studentske omladine, str. 76.

6 Gross, Studentski pokret 1875.-1914., str. 458. 
Mislav Gabelica: Mladohrvatski pokret do odvajanja od Starčevićeve hrvatske stranke prava... Zb. Odsjeka povij. znan. Zavoda povij. druš. znan. Hrvat. akad. znan. umjet., 34 (2016), str. 213-238

Napredne omladine na Sveučilištu. Ova je omladina do 1903. godine djelovala samostalno. ${ }^{7}$ Od 1903. do 1904. godine pristajala je uz Hrvatsku stranku prava, nastalu fuzijom matice Stranke prava i Neodvisne narodne stranke, ${ }^{8}$ da bi nakon toga pristala uz Naprednu stranku (Hrvatsku pučku naprednu stranku), koju je 1904. godine ustrojila prva generacija Napredne omladine. ${ }^{9}$

Od 1895. do 1914. godine poligon za odmjeravanje snaga studentskih grupacija na Sveučilištu u Zagrebu bili su izbori za upravni odbor Hrvatskog akademskog potpornog društva (HAPD), koji su se održavali početkom svake školske godine. ${ }^{10}$ Mada u hrvatskoj historiografiji prevladava mišljenje da su izborne borbe za upravni odbor tog društva oduvijek bile oštre, te da je upravni odbor HAPD-a oduvijek predstavljao samo onu političku grupaciju na Sveučilištu koja je te godine bila najjača, ${ }^{11} \mathrm{u}$ vrijeme dominacije frankovačke mladeži na zagrebačkom Sveučilištu, Hrvatsko pravo, list Čiste stranke prava, ne spominje borbe prigodom izbora za upravu HAPD-a. Od školske godine 1895./1896. do 1900./1901., u tom listu nema nikakve naznake stranačke obojenosti izbora za upravni odbor HAPD-a, te nikakvog trijumfalizma nakon izbora novih uprava. $U$ to vrijeme sve vijesti vezane uz te izbore isključivo su obavijesti da je izabrana nova uprava, nakon čega slijede pozivi građanima da doniraju priloge za HAPD. Vijesti o tom društvu su izvještaji o prikupljenim donacijama te o priredbama, koje je to društvo priređivalo kako bi prikupilo donacije. ${ }^{12}$

Osim toga, u tom razdoblju upravni odbor toga društva nisu činili isključivo simpatizeri Čiste stranke prava. Uz izuzetak upravnog odbora HAPD-a, izabranog koncem 1896. godine, kojem se na čelu nalazio tadašnji student prava i budući frankovački vođa Aleksandar Horvat, svi ostali predsjednici upravnog odbora HAPD od školskih godina 1895./1896. do 1901./1902. bili su anonimni pojedinci, ${ }^{13}$ koji nakon svršetka studija nisu ostavili značajnijeg traga u hrvatskom javnom životu. Uzme li se u obzir da su sinovi Josipa Franka, Vladimir i Ivo, sudjelovali u paljenju mađarske zastave 1895. godine prilikom posjete kralja Franje Josipa I. Zagrebu, ${ }^{14}$ te da je povod raskolu u Stranci prava bio taj, što je vođa protufrankovačke struje u Stranci prava,

7 Luetić, Studenti Sveučilišta u Zagrebu (1874.-1914.), str. 373-382.

8 Stjepan Matković, Čista stranka prava 1895.-1903., Zagreb 2001., str. 162.

9 Gross, Nacionalne ideje studentske omladine, str. 79-83.

10 O Hrvatskom akademskom potpornom društvu vidi: Luetić, Hrvatsko akademsko potporno društvo, str. 311-332.

11 Gross, Studentski pokret 1875.-1914., str. 457; Luetić, Hrvatsko akademsko potporno društvo, str. 325-326

12 Mjestne viesti, Hrvatsko pravo, br. 307, Zagreb, 9. studenoga 1896.; Mjestne viesti, Hrvatsko pravo, br. 603, 6. studenoga 1897.; Mjestne viesti, Hrvatsko pravo, br. 902, 7. studenoga 1898.; Mjestne viesti, $\mathrm{Hr}$ vatsko pravo, br. 1201, 6. studenoga 1899.; Mjestne viesti, Hrvatsko pravo, br. 1504, 12. studenoga 1900.

13 Spomenica na proslavu 40 godišnjice opstanka Hrvatskog akademskog podpornog društva na hrvatskom kraljevskom Sveučilištu Franje Josipa I. u Zagrebu, Zagreb 1914., str. 14. To su bili za šk. godinu 1895./1896. Ivo Kasunović, šk. godinu 1897./1898. Vjekoslav Pacher, šk. godinu 1898./1899. Slavo Dragić, šk. godinu 1899./1900. Mirko Brežan i šk. godinu 1900./1901. Josip Joanides.

14 O spaljivanju mađarske zastave vidi: Matković, Čista stranka prava, str. 297-299; Peršić, Kroničarski spisi, str. 79-82; Ljerka Racko, Spaljivanje mađarske zastave 1895. godine u Zagrebu, Radovi Zavoda za hrvatsku povijest, god. 23, br. 1, Zagreb 1990., str. 233-246. 
Mislav Gabelica: Mladohrvatski pokret do odvajanja od Starčevićeve hrvatske stranke prava... Zb. Odsjeka povij. znan. Zavoda povij. druš. znan. Hrvat. akad. znan. umjet., 34 (2016), str. 213-238

Fran Folnegović, javno osudio paljenje mađarske zastave ${ }^{15}$ može se pretpostaviti da je studentska mladež koja je pristajala uz Čistu stranku prava podržavala čin paljenja mađarske zastave. Međutim, predsjednici HAPD-a u vrijeme dominacije frankovačke mladeži na Sveučilištu: Ivo Kasunović, Vjekoslav Pacher i Slavo Dragić, našli su se među rijetkim studentima koji su se 1895. godine na saslušanju povodom paljenja mađarske zastave izjasnili nesolidarnima s učesnicima tog čina. ${ }^{16}$ Među onima koji su se izjasnili nesolidarnima s učesnicima tog čina nalazili su se i drugi članovi uprave HAPD-a iz razdoblja frankovačke dominacije na Sveučilištu: tajnik HAPD-a za šk. godinu 1896./97. Mirko Horvatin, te odbornik za tu godinu Krunoslav Babić. ${ }^{17}$

Moguće je da su navedeni članovi uprave HAPD-a pripadali mladeži koja se okupljala oko matice Stranke prava, odnosno domovinaša. U kasnijem je razdoblju zabilježeno da su domovinaška i frankovačka mladež na Sveučilištu surađivale na izborima za HAPD. Primjerice, na izborima za HAPD, održanima koncem 1901. godine, Napredna omladina je pobijedila "združene protivnike", koje su činili "čista skupina" na Sveučilištu, te "skupina pristaša koalirane opozicije", ${ }^{18}$ koju su činile matica Stranke prava i Neodvisna narodna stranka. Isto tako, uoči izbora za školsku godinu 1902./1903., studenti koji su se okupljali oko Čiste stranke prava, “organizovani pod imenom Starčevićanske mladosti", te studenti koji su se kupili oko Stranke prava, "poznati pod imenom Pravaške mladosti", zaključili su ostati u svojim organizacijama, ali surađivati protiv Napredne omladine. ${ }^{19}$ Rezultat te suradnje bila je pobjeda "pravaške sveučilišne omladine" na izborima za HAPD te godine. ${ }^{20}$

Među odbornicima HAPD-a za vrijeme frankovačke dominacije na Sveučilištu bilo je i pripadnika Napredne omladine. Primjerice, odbornik HAPD-a za šk. godinu 1897./1898. Mirko Sporčić, ${ }^{21} \mathrm{u}$ to je vrijeme bio politički istomišljenik Stjepana Radića, ${ }^{22}$ jednog od tadašnjih vođa Napredne omladine. ${ }^{23}$ Blagajnik HAPD-a za šk. godinu 1900./1901., Miho Petranović, ${ }^{24}$ bio je pripadnik Napredne omladine te je sljedeće školske godine bio izabran za prvog predsjednika HAPD-a iz redova te omladine. ${ }^{25}$ Zbog svega navedenoga stoji tvrdnja frankovačke mladeži da su ogorčeni sukobi oko uprave HAPD-a, te praksa da tu upravu ustrojava samo pobjednik na

15 Matković, Čista stranka prava, str. 59-60.

16 Luetić, Studenti Sveučilišta u Zagrebu, str. 208.

17 Mjestne viesti, Hrvatsko pravo, Zagreb, br. 307, 9. studenoga 1896.

18 Milan Marjanović, Hrvatski pokret. Opažanja i misli na pragu novog narodnog preporoda g. 1903., sv. 2, Dubrovnik 1903., str. 31-35.

19 Domaće viesti, Hrvatsko pravo, br. 2114, 25. studenoga 1902.

20 Domaće viesti, Hrvatsko pravo, br. 2103, 12. studenoga 1902.

21 Mjestne viesti, Hrvatsko pravo, br. 603, 6. studenoga 1897.

22 Bogdan Krizman, Korespodencija Stjepana Radića 1885.-1918., knj. 1, Zagreb 1972., str. 274.

23 Branka Boban, Stjepan Radić - opus, utjecaji i dodiri, Radovi Zavoda za hrvatsku povijest, sv. 22, Zagreb 1989., str. 152-153.

24 Mjestne viesti, Hrvatsko pravo, br. 1504, 12. studenoga 1900.

25 Ante Hikec, Hrvatski študent, Hrvatski djak, god. 1, br. 2, veljača 1907., str. 32. 
Mislav Gabelica: Mladohrvatski pokret do odvajanja od Starčevićeve hrvatske stranke prava... Zb. Odsjeka povij. znan. Zavoda povij. druš. znan. Hrvat. akad. znan. umjet., 34 (2016), str. 213-238

izborima, započeli početkom 20. stoljeća, nakon što je Napredna omladina ojačala i ostvarila dominaciju na Sveučilištu. ${ }^{26}$

Starčevićanski studenti na Sveučilištu u Zagrebu u početku nisu bili formalno organizirani. Naime, oni su se do 1902. godine službeno predstavljali kao "Sveučilišni gradjani, pristaše čiste stranke prava" ${ }^{27}$ Do tog vremena ova mladež nije imala ni formalnog vodstva. Iz literature doznajemo da su vođe ove mladeži u prvo vrijeme njenog postojanja bili sinovi Josipa Franka te Aleksandar Horvat, Zvonimir Vukelić i Osman Nuri Hadžić, kojima je zajedničko bilo da su sudjelovali u protumađarskim demonstracijama 1895. godine, tijekom kojih je spaljena mađarska zastava. ${ }^{28}$ Međutim, nigdje ne nalazimo obavijesti da su oni bili i formalno potvrđeni za vođe starčevićanske mladeži na nekom službenom skupu te mladeži, te je najvjerojatnije da im je legitimitet davalo ili to što su bili sinovi predsjednika stranke, ili to što su sudjelovali u navedenim demonstracijama.

Od 1902. godine frankovačka mladež na Sveučilištu službeno se počinje nazivati "Starčevićanskom mladosti", te se po prvi puta spominje dužnost "predsjednika" te mladeži, koju je te godine obnašao student prava Ivo Elegović. ${ }^{29}$ Sam Elegović je 1903. godine pisao da su unazad "godina danah" u hrvatskoj javnosti učestali napadi na politički nauk Ante Starčevića i na Čistu stranku prava, zbog čega je "na bojno polje izašla organizirana garda čiste stranke prava, koja se je iz trajne odanosti Anti Starčeviću i njegovim načelom ponosno prozvala Starčevićanska mladost". ${ }^{30} \mathrm{Ovu}$ Starčevićansku mladost, "organiziranu gardu" Čiste stranke prava, nije sačinjavala samo frankovačka sveučilišna mladež, nego "sjedinjena starčevićanska djačka i radnička omladina", koja je bila u "tiesnom dodiru s hrvatskom radničkom strankom", ${ }^{11}$ radničkom podružnicom Čiste stranke prava. ${ }^{32}$ Prema Josipu Franku, ovako organizirana Starčevićanska mladost trebala je biti "vojska", koja će "korisno djelovati na političku organizaciju naše javne borbe". ${ }^{33}$ Ova je stranačka "vojska" sudjelovala i u "pravim" bitkama, te su u ožujku 1904. združeni frankovački sveučilištarci i radnici sudjelovali u višednevnim sukobima na zagrebačkim ulicama protiv združenih naprednjaka i socijalističkog radništva, protiveći se odluci srpskih studenata na Sveučilištu da pođu gradom pod srbijanskom zastavom. ${ }^{34}$

Unutar Starčevićanske mladosti čini se da je postojao poseban studentski odsjek, te odsjek što su ga zajednički činili studenti i radnici. Naime, u izvještaju o

26 Ivo Mikinac, Izbori za Hrvatsko akademsko potporno društvo, Mlada Hrvatska, god. 2, br. 2, prosinac 1908., str. 46-47.

27 Izjava, Hrvatsko pravo, br. 1856, 17. siječnja 1902.

28 Matković, Čista stranka prava, str. 192.

29 Domaće viesti, Hrvatsko pravo, br. 2125, 9. prosinca 1902. Sljedeće godine, predsjednikom Starčevićanske mladosti postao je Hinko Petrović.

30 Ivo Elegović, Glas starčevićanske mladosti, Hrvatsko pravo, br. 2316, 1. kolovoza 1903.

31 Zrinsko-frankopanski komers, Hrvatsko pravo, br. 1946, 5. svibnja 1902.

32 Matković, Čista stranka prava, str. 226-241.

33 Zrinsko-frankopanski komers, Hrvatsko pravo, br. 1948, 7. svibnja 1902.

34 Izjava starčevićanske sveučilišne mladosti, Hrvatsko pravo, br. 2506, 21. ožujka 1904.; Izjava Hrvatske radničke stranke, Hrvatsko pravo, br. 2508, 23. ožujka 1904. 
Mislav Gabelica: Mladohrvatski pokret do odvajanja od Starčevićeve hrvatske stranke prava... Zb. Odsjeka povij. znan. Zavoda povij. druš. znan. Hrvat. akad. znan. umjet., 34 (2016), str. 213-238

sastancima Sveučilišne mladosti navodi se da su se "pristaše čiste stranke prava na sveučilištu (prvo) jače privili jedan uz drugoga, a onda sami organizirani prionuli uz zajednički rad s hrvatskom radničkom strankom". Zatim su zaredala posebna sijela starčevićanskih studenata, te posebna, skupna sijela studenata i radnika. ${ }^{35}$

Od 1904. godine Starčevićanska mladost se u tisku službeno počinje nazivati Starčevićanskom akademskom mladosti, što implicira da je napuštena skupna organizacija frankovačkih sveučilištaraca s frankovačkim radništvom. Novost u organizaciji frankovačkih studenata bila je i ta što su te godine predstavnici Starčevićanske akademske mladosti prvi puta delegirani u vrhovno stranačko tijelo, egzekutivni odbor Starčevićeve hrvatske stranke prava, kako se od te godine prozvala Čista stranka prava. ${ }^{36}$ Ova će se praksa nastaviti i u narednim godinama. ${ }^{37}$

U ovo vrijeme odnosi starčevićanske sveučilišne mladeži i njene matične stranke nisu uvijek bili idealni. Jedan od kasnijih disidenata Starčevićeve hrvatske stranke prava, Ante Pavelić stariji, u neobjavljenim je memoarima pisao da se od 1903. godine među "mladjom starčevićanskom inteligencijom" stvorilo nezadovoljstvo nedovoljno oštrim pisanjem stranačkog glasila protiv Mađara i nagodbenog sustava u Hrvatskoj, za što da se prozivalo Josipa Franka, te da je to nezadovoljstvo bilo prisutno i u narednim godinama. ${ }^{38}$ Josip Frank je 1904. godine govorom, u kojem je naveo da se starčevićanska sveučilišna mladež ne želi niti odcijepiti od svoje stranke niti postati "posebno krilo" u njoj, potvrdio postojanje glasina o nezadovoljstvu starčevićanske sveučilišne mladeži svojom matičnom strankom. ${ }^{39}$ Sredinom 1905. godine Hrvatsko pravo je demantiralo glasine da je starčevićanska sveučilišna mladost tih dana održala sastanak na kojem da se "prigovaralo pasivitetu naše stranke prema klerikalnom pokretu", te "dvoličnom pisanju našeg lista prema Madjarima" ${ }^{40}$

Unatoč navodnom nezadovoljstvu Josipom Frankom i službenom stranačkom politikom, tadašnji predvodnici starčevićanske sveučilišne mladeži u kasnijem su političkom životu ostali lojalni Josipu Franku, te su neki od njih nakon svršetka studija dobili značajan utjecaj i značajne funkcije u stranci. Prema riječima kasnijeg stranačkog disidenta Mile Starčevića, njega se izguralo iz vodstva stranke kada su Frankovi savjetnici umjesto njega postali Iso Kršnjavi te "direktorij četvorice", koji su činili Aleksandar Horvat, Vladimir Frank, Ivo Elegović i Karlo Bošnjak. Ovo nezadovoljstvo je rezultiralo njegovim napuštanjem stranke. ${ }^{41}$ I kasniji predvodnici starčevićanske sveučilišne mladeži, predsjednici Starčevićanske akademske mladosti od

35 Starčevićanski sastanci, Hrvatsko pravo, br. 1978, 14. lipnja 1902.

36 Glavna skupština SHSP, Hrvatsko pravo, br. 2607, 23. srpnja 1904.

37 Eksekutivni odbor, Hrvatsko pravo, br. 2997, 10. studenoga 1905.

38 Hrvatska (HR)-Hrvatski državni arhiv (HDA), fond: 1801 - Razne osobe XIX.-XX., Rukopisna ostavština Ante Pavelića starijeg, Memoari, str. 18.

39 Govor zastupnika naroda dra. Josipa Franka izrečen u saborskoj sjednici od 8. veljače 1904., Hrvatsko pravo, br. 2484, 24. veljače 1904.

40 Domaće viesti, Hrvatsko pravo, br. 2850, 15. svibnja 1905.

41 Stenografski zapisnik Sabora kraljevina Hrvatske, Slavonije i Dalmacije, petogodišta 1913.-1918., svezak 1, str. 1128. 
Mislav Gabelica: Mladohrvatski pokret do odvajanja od Starčevićeve hrvatske stranke prava... Zb. Odsjeka povij. znan. Zavoda povij. druš. znan. Hrvat. akad. znan. umjet., 34 (2016), str. 213-238

1905. do 1907. godine: Joso Spasoje Fattori, ${ }^{42}$ Tomo Kumičić, ${ }^{43}$ te Muhamed Fahrudin Tančica, ${ }^{44}$ ostali su lojalni vodstvu stranke, mada nisu doživjeli toliki uspon u stranačkoj hijerarhiji.

\section{Hrvatski katolički pokret i pokret Hrvatske napredne omladine}

Početkom 20. stoljeća na omladinsku političku scenu u Hrvatskoj stupila je katolička mladež. Njen istup dogodio se u sklopu pokreta za obranu katoličkih načela u hrvatskom javnom životu, poznatijeg pod imenom Hrvatski katolički pokret, što ga je Katolička crkva u Hrvatskoj vodila posredstvom svojih svjetovnjaka. ${ }^{45} \mathrm{U}$ okviru Hrvatskog katoličkog pokreta započelo je i organiziranje hrvatskih studenata, buduće nacionalne elite, na katoličkim načelima. Na tim su se načelima prvi organizirali hrvatski studenti sa Sveučilišta u Beču, ${ }^{46}$ koji su koncem 1905. godine počeli izdavati list Luč. Glavni cilj tog lista bio je organiziranje "svega hrvatskoga katoličkog đaštva" na katoličkim načelima. ${ }^{47}$ Pod "hrvatskim katoličkim đaštvom" uz studente se podrazumijevalo i srednjoškolce. ${ }^{48}$

Uključivanje srednjoškolaca u politički život bila je glavna karakteristika omladinskih pokreta u Hrvatskoj početkom 20. stoljeća. Prema tvrdnji frankovačke mladeži, dominaciju Napredne omladine na Sveučilištu u Zagrebu, ostvarenu početkom 20. stoljeća, omogućila je prethodna infiltracija naprednjačkih ideja među hrvatske srednjoškolce, koji do tada nisu bili politizirani. ${ }^{49}$ Da je Napredna omladina prva započela prodirati u srednje škole, potvrđuje i jedan pripadnik katoličke mladeži, koji je naveo da je u vrijeme osnutka prvih organizacija katoličkog đaštva, "dobar dio srednjoškolaca bio naprednjački", dok su ostali srednjoškolci bili "indiferentni". ${ }^{50} \mathrm{~S}$ druge strane, pripadnici Napredne omladine su tvrdili da je njihovo organiziranje po srednjim školama započelo kao reakcija na prodor "klerikalizma" u te ustanove. ${ }^{51}$

Sami su pripadnici Napredne omladine tog vremena svoj "pokret" držali bitno drugačijim od "pokreta" Napredne omladine starije generacije, koji je završio osnutkom Napredne stranke. Dok je stariji pokret imao “opće-narodni” karakter, noviji je

42 Odgovor naprednoj omladini, Hrvatsko pravo, br. 2882, 24. lipnja 1905.

43 Domaće viesti, Hrvatsko pravo, br. 3293, 8. studenoga1906.

44 Djačke vijesti, Mlada Hrvatska, god. 1, br. 1, siječanj 1908.

45 O Hrvatskom katoličkom pokretu vidi: Jure Krišto, Prešućena povijest. Katolička crkva u hrvatskoj politici 1850.-1918., Zagreb 1994.; Jure Krišto, Hrvatski katolički pokret (1903.-1945.), Zagreb 2004.; Zlatko Matijević, Slom politike katoličkog jugoslavenstva. Hrvatska pučka stranka u političkom životu Kraljevine SHS (1919.-1929.), Zagreb 1998.; Zlatko Matijević, Lučonoše ili herostrati? Prilozi poznavanju crkveno-nacionalne povijesti Hrvata početkom XX. stoljeća, Zagreb 2006.; Hrvatski katolički pokret (Zbornik radova s međunarodnog znanstvenog skupa održanog u Zagrebu i Krku od 29. do 31. ožujka 2001.), ur. Zlatko Matijević, Zagreb 2002.

46 Krišto, Prešućena povijest, str. 196-199.

47 Krišto, Hrvatski katolički pokret, str. 42.

48 Krišto, Prešućena povijest, str. 235.

49 Emanuel Latković, Kada ćemo pobijediti?, Mlada Hrvatska, god. 1, br. 1, siječanj 1908., str. 16-20.

50 Krišto, Prešućena povijest, str. 197.

51 Ivan N. Novak, Naš prvi zbor, Hrvatski djak, god. 4, br. 1, Zagreb, listopad 1909. 
Mislav Gabelica: Mladohrvatski pokret do odvajanja od Starčevićeve hrvatske stranke prava... Zb. Odsjeka povij. znan. Zavoda povij. druš. znan. Hrvat. akad. znan. umjet., 34 (2016), str. 213-238

pokret imao isključivo "đački" karakter. ${ }^{52} \mathrm{U}$ tom su smislu naprednjaci smatrali da je njihov noviji pokret počeo školske godine 1905./1906., kada su započele pripreme za izdavanje njihovog lista Hrvatski djak, te su o tom pokretu pisali kao o "srednjoškolskom pokretu kojem je temelj u sveučilišnim krugovima". Ovo je podrazumijevalo stvaranje jedinstvene naprednjačke organizacije, kojoj bi jezgru činila organizacija Napredne omladine sa Sveučilišta u Zagrebu, a u kojoj bi svoje predstavnike imale naprednjačke srednjoškolske organizacije iz svih hrvatskih zemalja, te predstavnici naprednjačke sveučilišne omladine sa ostalih Sveučilišta u Monarhiji na kojima su studirali hrvatski studenti. ${ }^{53}$

Međutim, Napredna omladina nikada nije uspjela stvoriti jedinstvenu organizaciju, koja bi okupljala i srednjoškolsku i studentsku naprednjačku mladež. Prve srednjoškolske naprednjačke organizacije počele su se osnivati 1907. godine. Početkom 1908. godine, na sastanku "predstavnika zagrebačkih srednjoškolskih organizacija" osnovana je "centralna organizacija naprednoga srednjoškolskoga djaštva", u koju su pozvani predstavnici naprednjačkih srednjoškolskih organizacija iz svih hrvatskih zemalja. ${ }^{54}$ Nije poznato je li ova organizacija zaživjela, tek je zabilježeno da je "centralni odbor" u Zagrebu primio na znanje da će se u kolovozu 1908. u Brodu održati "prvi pokrajinski zbor hrvatskog naprednoga djaštva iz Slavonije", što ga je potom i odobrio..$^{55}$

Napredna omladina na Sveučilištu u Zagrebu dugo vremena nije imala formalnu organizaciju. ${ }^{56}$ Tek je koncem 1907. godine osnovana Prosvjeta, prvo društvo Hrvatske napredne omladine na Sveučilištu u Zagrebu. ${ }^{57}$ Ovo je društvo trebalo postati jezgrom cjelokupne naprednjačke organizacije, pa je u veljači 1909. Prosvjeta proglašena "reprezentativnim tijelom Hrvatske napredne omladine", koje će službeno istupati u njeno ime. ${ }^{58}$ Društvo nije ostvarilo svoju svrhu, te je čini se ubrzo raspušteno. U kolovozu iste godine sazvan je "Prvi zbor Hrvatske napredne omladine", na kojem su njeni predstavnici iz svih hrvatskih zemalja raspravljali o zajedničkom programu i jedinstvenoj organizaciji. Na zboru je prihvaćen zajednički program, te je donesen zaključak o provedbi jedinstvene organizacije Hrvatske napredne omladine na čelu s njenim izvršnim odborom. ${ }^{59}$ Preduvjet za osnivanje ovog zajedničkog izvršnog odbora bilo je stvaranje organizacija Napredne omladine na Sveučilištu u Zagrebu te na ostalim sveučilištima u Monarhiji. Kako do toga nije došlo, ni zajednička organizacija Hrvatske napredne omladine nije provedena. ${ }^{60}$

\footnotetext{
52 Milivoj Blažeković, Klub Prosvjeta, Hrvatski djak, god. 1, br. 10, str. 253.

53 Naš pokret, Hrvatski djak, god. 1, br. 5, svibanj 1907.

54 Iz djačkog života, Hrvatski djak, god. 2, br. 3, ožujak 1908., str. 87-88.

55 Iz djačkog života, Hrvatski djak, god. 3, br. 2, listopad 1908., str. 50-54.

56 Luetić, Studenti Sveučilišta u Zagrebu (1874.-1914.), str. 383.

57 Iz djačkog života, Hrvatski djak, god. 1, br. 11/12, prosinac 1907., str. 316-317.

58 Iz djačkog života, Hrvatski djak, god. 3, br. 6, veljača 1909., str. 180.

59 Naš prvi zbor, Hrvatski djak, god. 4, br. 1, listopad 1909., str. 3-4.

60 Novak, Naše prilike, Hrvatski djak, god. 4, br. 5/6, travanj 1910., str. 118-123.
} 
Mislav Gabelica: Mladohrvatski pokret do odvajanja od Starčevićeve hrvatske stranke prava... Zb. Odsjeka povij. znan. Zavoda povij. druš. znan. Hrvat. akad. znan. umjet., 34 (2016), str. 213-238

Katolička mladež se u organizacijskom smislu pokazala puno sposobnijom od naprednjačke omladine. Katolička crkva je i prije početka Hrvatskog katoličkog pokreta okupljala srednjoškolce unutar Marijinih kongregacija, srednjoškolskih organizacija pod vodstvom isusovaca, koje su služile odgajanju mladeži u kršćanskome duhu s posebnim naglaskom na posvećivanju Blaženoj Djevici Mariji. ${ }^{61}$ Početkom Hrvatskog katoličkog pokreta, ove su kongregacije postale prva etapa u organiziranju hrvatskog katoličkog đaštva, u kojima su se odgajali budući katolički aktivisti. ${ }^{62}$ Pretvaranju Marijinih kongregacija u srednjoškolske organizacije Hrvatskog katoličkog pokreta prethodilo je osnivanje Hrvatskog katoličkog akademskog društva Domagoj na Sveučilištu u Zagrebu, koncem 1906. godine, nakon čega su "domagojci" započeli organizirati katoličke đake po srednjim školama ${ }^{63} u$ svim hrvatskim zemljama ${ }^{64}$ Poticaj za početak rada među srednjoškolskom omladinom na načelima Hrvatskog katoličkog pokreta dan je na prvom Hrvatsko-slovenskom zboru katoličkih srednjoškolaca, održanom u kolovozu 1907. u Zagrebu u organizaciji katoličke akademske omladine iz Zagreba i Beča, gdje je zaključeno da se otpočne s organiziranjem srednjoškolske mladeži. ${ }^{65}$

Srednjoškolske organizacije Hrvatskog katoličkog pokreta međusobno su bile organizacijski povezane unutar hrvatskih pokrajina. Tako se, primjerice, središnjica srednjoškolskih organizacija za Dalmaciju uspostavila u zadarskom sjemeništu. ${ }^{66}$ Srednjoškolske organizacije Hrvatskog katoličkog pokreta nisu bile neposredno vezane uz HKAD Domagoj, te druga hrvatska katolička akademska društva, koja su se osnivala po ostalim sveučilišnim centrima u Monarhiji, niti su ta akademska društva bila međusobno neposredno vezana, nego je njihova povezanost ostvarena posredstvom pojedinaca koji su pripadali tim organizacijama. Naime, 1910. godine je ustrojena organizacija Hrvatsko katoličko narodno đaštvo (Hrvatski katolički đački savez), u koji nisu ušle srednjoškolske i studentske organizacije Hrvatskog katoličkog pokreta, nego pojedinci, koje su te organizacije preporučivale. ${ }^{67}$ Ovaj je Hrvatski katolički đački savez bio uključen u Hrvatski katolički narodni savez, unutar kojeg su bile zastupljene sve "grane" Hrvatskog katoličkog pokreta. Vodeću ulogu unutar Hrvatskog katoličkog narodnog saveza, a time i čitavog Hrvatskog katoličkog pokreta, vremenom je preuzeo Hrvatski katolički seniorat, kojeg su uglavnom činili svršeni studenti, bivši članovi hrvatskih katoličkih akademskih društava. ${ }^{68}$

61 Krišto, Hrvatski katolički pokret, str. 39-40.

62 Krišto, Hrvatski katolički pokret, str. 43-44. O stajalištu Napredne omladine prema Marijinim kongregacijama, vidi: Prava svrha srednjoškolskih kongregacija, Hrvatski djak, god. 1, br. 5, svibanj 1907. str. 137-139.

63 Matijević, Slom politike katoličkog jugoslavenstva, str. 26-27.

64 Krišto, Hrvatski katolički pokret, str. 51.

65 Krišto, Prešućena povijest, str. 234-235.

66 Isto, str. 235.

67 Krišto, Hrvatski katolički pokret, str. 68.

68 Matijević, Slom politike katoličkog jugoslavenstva, str. 30-31. O Hrvatskom katoličkom senioratu vidi: Matijević, Lučnoše ili herostrati?, str. 55-96. 
Mislav Gabelica: Mladohrvatski pokret do odvajanja od Starčevićeve hrvatske stranke prava... Zb. Odsjeka povij. znan. Zavoda povij. druš. znan. Hrvat. akad. znan. umjet., 34 (2016), str. 213-238

\section{Mladohrvatski pokret u školskoj godini 1907./1908.}

Mladohrvatski pokret, koji je činila mladež koja je pristajala uz Starčevićevu hrvatsku stranku prava, nastao je oko 1907. godine. Te su godine objavljena "Pravila Starčevićanske mladosti". Tim je statutom usvojen jedinstven način ustroja starčevićanskih đačkih organizacija, te je stvoreno zajedničko tijelo starčevićanskih srednjoškolskih organizacija i Starčevićanske akademske mladosti. Prema statutu, "Starčevićanska mladost" je bila novostvorena organizacija koja se sastojala od "organizacije Starčevićanske akademske mladosti sa sjedištem u Zagrebu" te "srednjoškolskih starčevićanskih organizacija sa sjedištem u pojedinim mjestima njihova nastanka" ${ }^{69}$ U središnjem dijelu ovog statuta propisana su načela ustroja ne samo starčevićanskih srednjoškolskih organizacija, nego i Starčevićanske akademske mladosti. Određena su tijela uprave ovih organizacija, na čelu s upravnim odborom što su ga činili predsjednik, tajnik, blagajnik, potpredsjednik te određen broj odbornika, određen je način njihova izbora, revizija njihova poslovanja, te prava i dužnosti članova tih organizacija. ${ }^{70} \mathrm{Na}$ koncu je određeno da upravu Starčevićanske mladosti, kao zajedničke organizacije, vodi upravni odbor Starčevićanske akademske mladosti, čijoj sjednici "u koliko se radi o zajedničkim poslovima" imaju pravo prisustvovati po dva izaslanika "svake srednjoškolske organizacije". Navedeno je i da se Starčevićanska mladost smatra "sastavnim dijelom" Starčevićeve hrvatske stranke prava, te je propisano da su predsjednik i tajnik Starčevićanske akademske mladosti članovi egzekutivnog odbora te stranke. ${ }^{71}$

Prema ovom je statutu vidljivo da se starčevićanska mladež organizirala na način na koji se namjeravala organizirati i Hrvatska napredna omladina, koja u tomu nije imala uspjeha. Središte organizacije cjelokupne starčevićanske omladine bila je organizacija starčevićanske mladeži na Sveučilištu u Zagrebu, Starčevićanska akademska mladost (SAM), u čije su vrhovno tijelo srednjoškolske organizacije iz svih hrvatskih zemalja po potrebi slale svoje delegate. U tu svrhu je vodstvo SAM-a s njenog predsjednika pomaknuto na upravni odbor, na čelu s predsjednikom, što je predstavljalo korak dalje u organizaciji starčevićanske sveučilišne mladeži.

Od 1906. godine počele su se osnivati starčevićanske organizacije po srednjim školama, ${ }^{72}$ te je do konca 1908. godine osnovano 18 tih organizacija ${ }^{73}$ po svim hrvatskim zemljama, osim u Istri. ${ }^{74} \mathrm{U}$ početku su unutar tih organizacija djelovali i đaci, koji su istovremeno bili članovi i Marijinih kongregacija na istim zavodima, kao što

9 Pravila Starčevićanske mladosti, Zagreb 1907., str. 3-4.

70 Isto, str. 5-11.

71 Isto, str. 12-13.

72 Dopisi, Mlada Hrvatska, god. 2, br. 8, lipanj 1909., str. 233.

73 Srednjoškolski vijesnik, Mlada Hrvatska, god. 2, br. 1, studeni 1908., str. 31.

74 Srednjoškolski vijesnik, Mlada Hrvatska, god. 2, br. 2, prosinac 1908., str. 63. 
Mislav Gabelica: Mladohrvatski pokret do odvajanja od Starčevićeve hrvatske stranke prava... Zb. Odsjeka povij. znan. Zavoda povij. druš. znan. Hrvat. akad. znan. umjet., 34 (2016), str. 213-238

je bio slučaj na vinkovačkoj gimnaziji ${ }^{75} \mathrm{i}$ u splitskim srednjim školamaa, ${ }^{76}$ dok je s druge strane na sarajevskoj gimnaziji bio slučaj da su unutar tamošnje Marijine kongregacije djelovali i đaci koji su bili simpatizeri Starčevićeve hrvatske stranke prava. ${ }^{77}$ U to vrijeme ni HKAD Domagoj nije izlazio samostalno na izbore za HAPD, nego su njegovi članovi, ako su glasovali, glasovali za listu SAM-a. Zbog toga su naprednjaci domagojce otprilike definirali kao struju unutar starčevićanske mladeži, među kojom još nije nastala razdioba na kulturno-socijalnim pitanjima. ${ }^{78}$ Postojanje dviju struja, katoličke i liberalne unutar starčevićanske mladeži, navodi i katolička Luč. ${ }^{79}$ Prema tvrdnji samih starčevićanaca, katolička struja unutar njihovih redova je težila tomu da starčevićanska mladež bude političko krilo, a katolička mladež kulturnosocijalno krilo jedne te iste mladeži ${ }^{80}$

Ova je razdioba mladeži, koja je dijelila ista politička stajališta, započela izdavanjem lista starčevićanske mladeži Mlada Hrvatska u siječnju 1908. godine. List je navodno pokrenut na poticaj starčevićanskih srednjoškolaca, kako bi olakšao komunikaciju starčevićanskih akademičara sa starčevićanskim srednjoškolskim organizacijama. ${ }^{81}$ Te je školske godine predsjednik Starčevićanske akademske mladosti bio Budislav Grgur Angjelinović, potpredsjednik Pavle Horvat, tajnik Drago Oršanić, a blagajnik Zlatko Grotić. Odbornici su bili Fran Galović, Emanuel Latković, David Wohl, Zvonimir Milković te Drago Šaffar. ${ }^{82}$ Prvi urednici Mlade Hrvatske bili su Budislav G. Angjelinović, Fran Galović i Zlatko Grotić. ${ }^{83}$

U prvom broju Mlade Hrvatske, njeno uredništvo je navelo da će podržavati borbu katoličke mladeži za obranu katoličkih načela ukoliko katolički đaci "ne zastrane putem intolerance i zasukanosti". Uredništvo je navelo da mu je stalo do savezništva s katoličkom mladeži jer se među njima nalaze "i neki mladji naši istomišljenici, za koje se nadamo, da će u javnoj borbi, koja nas čeka, boriti se s nama bok uz bok". ${ }^{84}$ Uredništvo Luči je smatralo da bi ta suradnja bila moguća kada bi se Mlada Hrvatska držala isključivo političkih pitanja, a kada bi kulturno-socijalna pitanja prepustila katoličkoj mladeži, budući da "ogromna većina - ako ne svi - naši drugovi misle u političkim pitanjima kao i oni oko Mlade Hrvatske i to ne nestalno nego oduševljeno i požrtvovno". Međutim, uredništvo Luči je već u prvom broju lista starčevićanske mladeži primijetilo niz primjera, gdje se ta mladež bavila kulturno-socijalnim pitanjima s Luči neprihvatljivog liberalnog stajališta, što je tu mladež, prema mišljenju

75 Dopisi, Mlada Hrvatska, god. 2, br. 2, prosinac 1908., str. 52-54.

76 Dopisi, Mlada Hrvatska, god. 1, br. 3/4, ožujak-travanj 1908., str. 117; Dopisi, Mlada Hrvatska, god. 2, br. 8, lipanj 1909., str. 233.

77 Dopisi, Mlada Hrvatska, god. 2, br. 2, prosinac 1908., str. 56-57.

78 Iz djačkoga života, Hrvatski djak, god. 1, br. 5, svibanj 1907.

79 Prvi srednjoškolski starčevićanski sastanak, Luč, god. 4, br. 1, rujan 1908., str. 21-29.

80 Sa prvog starčevićanskog srednjoškolskog sastanka, Mlada Hrvatska, god. 2, br. 2, prosinac 1908., str. 41-42.

81 Zamislite se malo!, Mlada Hrvatska, god. 3, br. 4/5, siječanj/veljača 1910., str. 91.

82 Djačke vijesti, Mlada Hrvatska, god. 1, br. 1, siječanj 1908., str. 27-28.

83 Djačke vijesti, Mlada Hrvatska, god. 1, br. 1, siječanj 1908., str. 26.

84 Djačke vijesti, Mlada Hrvatska, god. 1, br. 1, siječanj 1908., str. 32. 
Mislav Gabelica: Mladohrvatski pokret do odvajanja od Starčevićeve hrvatske stranke prava... Zb. Odsjeka povij. znan. Zavoda povij. druš. znan. Hrvat. akad. znan. umjet., 34 (2016), str. 213-238

Luči, činilo bliskom Naprednoj omladini. Zbog toga je Luč uzvratila Mladoj Hrvatskoj da ako hoće savez, odnosno borbu "bok uz bok", o kulturno-socijalnim pitanjima će morati pisati u skladu s katoličkim načelima. ${ }^{85}$

Budući da se Luč nije odrekla svojih "zasukanih" načela, a Mlada Hrvatska nije odustala od stajališta koja su vrijeđala vjerske osjećaje katoličke mladeži, spor između ovih dviju đačkih skupina je kulminirao, te je tijekom 1908. i 1909. godine urodio raskolom $u$ onim srednjoškolskim organizacijama, $u$ kojima su te dvije skupine dotad djelovale zajedno. Iz splitske i vinkovačke starčevićanske srednjoškolske organizacije isključeni su članovi koji su ujedno bili i članovi neke od "klerikalnih organizacija" ${ }^{86}$ Dubrovačka starčevićanska srednjoškolska organizacija je nakon vijećanja zaključila da Mladu Hrvatsku drži svojim listom, te je osudila napade katoličke mladeži na nju. Nakon toga je ova organizacija navodno "u svojoj nutrini" ojačala, postavši "jedinstvena u misli starčevićanskoj". ${ }^{87} \mathrm{Da}$ tomu nije bilo tako navodi vijest da se početkom 1909. godine održala sjednica organizacije starčevićanske srednjoškolske mladosti u Dubrovniku, na kojoj su "klerikalci" pokušali osvojiti njezin upravni odbor. ${ }^{88}$

Iz Marijine kongregacije ustrojene na sarajevskoj gimnaziji isključeni su oni srednjoškolci, koji su se pretplatili na Mladu Hrvatsku. ${ }^{89}$ "Klerikalna mladež" koja je ostala u toj kongregaciji i dalje se predstavljala kao "starčevićanska mladež" ${ }^{90}$ Na zagrebačkoj gornjogradskoj gimnaziji je Mlada Hrvatska, koja je ondje do sukoba s katoličkim đaštvom imala najviše pretplatnika, izbijanjem sukoba navodno potpuno izgubila pretplatnike. ${ }^{91}$ Sukob se odrazio i na mladež Zagrebačkog sveučilišta, gdje je koncem 1908. godine HKAD Domagoj prvi puta samostalno izašlo na izbore za HAPD. ${ }^{92}$

Uz sukob s katoličkom mladeži izvan i unutar svojih redova, na cjelovitost starčevićanske mladeži negativno se odrazio i raskol unutar Starčevićeve hrvatske stranke

85 Starčevićanska omladina u svom glasilu, Luč, god. 3, br. 5, veljača 1908., str. 255-263. O primjedbama Luči na prvi broj Mlade Hrvatske vidi: Gross, Nacionalne ideje studentske omladine, str. 85. O sukobu domagojaca i mladohrvata vidi: Artuković, Politički nazori Josipa Matasovića, str. 171-174. Artuković kao "bitni uzrok" sukoba mladohrvata s "klerikalnom grupom" smatra simpatije, koje je "klerikalna grupa" na Zagrebačkom sveučilištu gajila za ustroj kršćansko-socijalne stranke, koja bi bila konkurencija Starčevićevoj hrvatskoj stranci prava. Vidi i: Krišto, Hrvatski katolički pokret, str. 74-75. Krišto početak sukoba između mladohrvata i domagojaca pomiče u kasnije razdoblje, odnosno u 1911. godinu te smatra da je suština toga sukoba bila u tomu, što su se domagojci organizirali na konfesionalnoj osnovi, zbog čega su između ostaloga odbijali muslimane od pravaškog političkog programa.

86 Dopisi, Mlada Hrvatska, god. 2, br. 1, studeni 1908., str. 22-24; Dopisi, Mlada Hrvatska, god. 2, br. 2, prosinac 1908., str. 52-54. Na vinkovačkoj gimnaziji, gdje se školovao do 1911. godine, starčevićansku srednjoškolsku organizaciju pomogao je ustrojiti hrvatski povjesničar Josip Matasović. Matković, Josip Matasović i "mladohrvatski” pokret, str. 152.

87 Dopisi, Mlada Hrvatska, god. 2, br. 4, veljača 1909., str. 116-117.

88 Dopisi, Mlada Hrvatska, god. 2, br. 6/7, travanj 1909., str. 200-201.

89 Dopisi, Mlada Hrvatska, god. 2, br. 2, prosinac 1908., str. 56-57.

90 Dopisi, Mlada Hrvatska, god. 2, br. 3, siječanj 1909., str. 87.

91 Dopisi, Luč, god. 3., br. 9/10, lipanj 1908., str. 573.

92 Izbor za Hrvatsko akademsko potporno društvo, Mlada Hrvatska, god. 2, br. 2, prosinac 1908., str. 46-49. 
Mislav Gabelica: Mladohrvatski pokret do odvajanja od Starčevićeve hrvatske stranke prava... Zb. Odsjeka povij. znan. Zavoda povij. druš. znan. Hrvat. akad. znan. umjet., 34 (2016), str. 213-238

prava, koji se dogodio koncem travnja 1908. istupom članova stranke pod vodstvom Mile Starčevića iz stranačkog zastupničkog kluba. ${ }^{33}$ Na izvanrednoj skupštini Starčevićanske akademske mladosti, na kojoj se skupilo "preko 60 kolega", velikom je većinom glasova donesena rezolucija, kojom su disidenti, tzv. milinovci, najoštrije osuđeni. Protiv rezolucije glasovalo je devet članova SAM-a, od kojih su se šestorica, među kojima su bile "kolege Draženović, Pavelić i Starčević", izjasnili "da ne pripadaju ni jednoj grupi", dok su trojica pristala uz disidente. ${ }^{94}$

Grupa neutralaca predlagala je da se SAM potpuno odvoji od Starčevićeve hrvatske stranke prava, ali da ne podrži ni disidente, nego da se ustroji kao posve samostalna grupa. Tomu se veći dio SAM-a odupro, ${ }^{95}$ te su simpatizeri milinovaca isključeni iz te organizacije. ${ }^{96}$ Koncem 1908. godine, uoči izbora za HAPD, na Zagrebačkom sveučilištu je Organizacija Starčevićanaca akademičara, koja je pristajala uz milinovce. Predsjednik ovog studentskog društva bio je prvi predsjednik HKAD Domagoj ${ }^{97}$ Ferdo Pavelić, potpredsjednik je bio Stjepan Maraković, tajnik Krešimir Hajdić, blagajnik Antun Rosandić, odbornici Juraj Filipović, Ljubomir Nardini, Vicko Radojković, Eugen Sgurić, te revizori Ante Brajković i Andrija Ćurlin. ${ }^{98}$

$\mathrm{Na}$ osipanje starčevićanskih redova u prvoj fazi mladohrvatskog pokreta djelovalo je i približavanje dijela starčevićanske mladeži Naprednoj omladini. Ovo približavanje započelo je koncem travnja 1908., kada je Napredna omladina organizirala studentski štrajk ${ }^{99}$ zbog povrede studentske autonomije koju je počinila vlada bana Pavla Raucha umirovljenjem sveučilišnog profesora Đure Šurmina, člana Hrvatske pučke napredne stranke. Štrajk je u svibnju 1908. rezultirao ispisivanjem velike većine studenata sa Sveučilišta u Zagrebu te njihovim upisivanjem tijekom ljetnog semestra iste godine na druga sveučilišta, većinom u Pragu. ${ }^{100}$

Prema tvrdnji hrvatske historiografije, ovaj je studentski štrajk izazvao "reakciju klerikalnih i frankovačkih krugova", mada su u njemu sudjelovali i starčevićanski sveučilištarci. ${ }^{101}$ Ova je tvrdnja utemeljena na stajalištu jugoslavenske historiografije, da su "frankovci i klerikalci s negodovanjem očekivali daljnje jačanje naprednjaštva u direktnom kontaktu s Masarykovim utjecajem u Pragu" ${ }^{102}$ Međutim, Starčevićeva hrvatska stranka prava je od početka studentske akcije pa do njenog svršetka u listopadu 1908., gotovo bez iznimke podržavala studentski štrajk i odlazak studenata sa

93 O raskolu u SHSP vidi: Mirjana Gross, Hrvatska uoči aneksije Bosne i Hercegovine, u: Istorija XX. veka, br. 3, Beograd 1962., str. 212-215.

94 Starčevićansko djačtvo i raskol, Hrvatsko pravo, br. 3732, 27. travnja 1908.

95 Iz organizacije starčevićanaca akademičara, Hrvatska sloboda, br. 162, Zagreb, 7. studenoga 1908.

96 Sveučilištarci starčevićanci!, Hrvatska sloboda, br. 151, 26. listopada 1908.

97 Krišto, Hrvatski katolički pokret, str. 48, 52.

98 Domaće viesti, Hrvatska sloboda, br. 155, 30. listopada 1908.

99 Iz djačkog života, Hrvatski djak, god. 2, br. 5, svibanj 1908., str. 148-151.

100 O štrajku i literaturi vezanoj za taj događaj vidi: Luetić, Studenti Sveučilišta u Zagrebu, str. 389-390. Vidi i stajalište Pavla Raucha o istom događaju u: Veridicus, Hrvatska u godini 1907. i 1908., Zagreb 1908., str. 12-13.

101 Luetić, Studenti Sveučilišta u Zagrebu, str. 390.

102 Gross, Studentski pokret 1875.-1914., str. 464. 
Mislav Gabelica: Mladohrvatski pokret do odvajanja od Starčevićeve hrvatske stranke prava... Zb. Odsjeka povij. znan. Zavoda povij. druš. znan. Hrvat. akad. znan. umjet., 34 (2016), str. 213-238

Sveučilišta u Zagrebu, pri čemu nije imala ništa protiv toga što je većina studenata, pa i Starčevićanaca, za nastavak svog školovanja izabrala Prag. ${ }^{103}$ Prema tvrdnji vođe starčevićanske mladeži Budislava G. Angjelinovića, Starčevićeva hrvatska stranka prava je zauzela stajalište da je štrajk "interno djačko pitanje", te su pojedini zastupnici te stranke, primjerice Vladimir Frank, pomagali štrajkašima. ${ }^{104}$ Jedini tko je od istaknutih članova te stranke podržao štrajk, ali je osudio odlazak hrvatskih studenata na druga sveučilišta, bio je sveučilišni profesor Iso Kršnjavi, od čijeg se mišljenja stranka javno ogradila. ${ }^{105}$

Predsjednik Starčevićanske akademske mladosti, Budislav G. Angjelinović već je na prvoj studentskoj skupštini, koja je proglasila štrajk, proglašen njenim predsjednikom. Angjelinović je nakon ustroja središnjeg štrajkaškog tijela, "centralnog alademskog odbora" što su ga činila četiri naprednjaka, četiri Starčevićanca i četiri Srbina, proglašen i predsjednikom tog tijela. ${ }^{106}$ Prema tvrdnji katoličkog tiska, koje je podržavalo štrajk, ali se nije slagalo s odlaskom studenata sa Zagrebačkog sveučilišta, Angjelinoviću je laskalo što ga protivnici guraju na najviše položaje, zbog čega je prigrlio inicijativu Napredne omladine da se ode sa Zagrebačkog sveučilišta, te je tu ideju silom nametao i među starčevićanskim studentima, velik dio kojih nije podržavao tu ideju. ${ }^{107}$ Angjelinović je sam pisao da u početku nije prihvaćao ideju o odlasku sa Sveučilišta, no jednom kada je tu ideju prihvatio odlučio ju je provesti do krajnosti. ${ }^{108}$ Pisao je i da su svi starčevićanski studenti bili za štrajk, ali da nisu svi bili za odlazak sa Sveučilišta, no da se ta manjina naposljetku "zaključku većine pokorila". 109

Svršetkom štrajka među starčevićanskim je sveučilištarcima prevladalo mišljenje da štrajk nije uspio te da nije trebalo ići sa Zagrebačkog sveučilišta. Samo je Angjelinović još branio opravdanost tog poteza. ${ }^{110}$ Među starčevićanskim sveučilištarcima koji nisu prihvaćali odlazak sa Zagrebačkog sveučilišta nalazio se i Krešimir Kovačić, koji je 1908. godine u jednoj brošuri izvrgnuo ruglu štrajk, njegove vođe i odluku da se ode sa Zagrebačkog sveučilišta. ${ }^{111}$ Nedugo potom Hrvatsko pravo je objavilo otvoreno pismo upućeno B. G. Angjelinoviću, koje je bilo potpisano inicijalima S.S.-

103 Rauchovo masreglovanje našeg sveučilišta, Hrvatsko pravo, br. 3734, 29. travnja 1908.; Rauch-Czernkovicheva nasilja na sveučilištu, Hrvatsko pravo, br. 3735, 30. travnja 1908.; Sveučilište zatvoreno!, Hrvatsko pravo, br. 3736, 1. svibnja 1908.

104 Budislav G. Angjelinović, Exodus hrvatskih sveučilištaraca sa Rauch-Bauer-Steinfl-Simonove univerze, Hrvatsko pravo, br. 3760, 30. svibnja 1908.

105 Bauerovci proti Kršnjaviju, Hrvatsko pravo, br. 3760, 30. svibnja 1908.

106 Iz djačkog života, Hrvatski djak, god. 2, br. 5, str. 150.

107 Fiat lux! Riječ hrvatskomu đaku i narodu upravlja Domagoj, hrvatsko katoličko akademsko društvo u Zagrebu, Zagreb 1909., str. 12.

108 Angjelinović, Lanjski štrajk i emigracija hrvatskih akademičara, Mlada Hrvatska, god. 2, br. 1, studeni 1908., str. 5.

109 Angjelinović, Exodus hrvatskih sveučilištaraca sa Rauch-Bauer-Steinfl-Simonove univerze, Hrvatsko pravo, br. 3760, 30. svibnja 1908.

110 Angjelinović, Lanjski štrajk i emigracija hrvatskih akademičara, Mlada Hrvatska, god. 2, br. 1, studeni 1908., str. 5-7.

111 Krešimir Kovačić, Povijest jedne pobune i štrajk mladeži u perzijskoj satrapiji. Sastavljeno po starinskim knjigama u pet kaputa, Zagreb 1908. 
Mislav Gabelica: Mladohrvatski pokret do odvajanja od Starčevićeve hrvatske stranke prava... Zb. Odsjeka povij. znan. Zavoda povij. druš. znan. Hrvat. akad. znan. umjet., 34 (2016), str. 213-238

H., pod kojima se vjerojatno krio Krešimir Kovačić. Autor je pisao da su se njegova predviđanja u vezi štrajka ostvarila, te se ispričao Angjelinoviću ako ga je “kojim satiričkim prizvukom" tijekom polemike o štrajku povrijedio. Pismo je upućeno zbog toga što je Angjelinović u međuvremenu napustio starčevićansku organizaciju. ${ }^{112}$

Prema tvrdnji katoličkog tiska, Angjelinović i još neki vođe starčevićanske mladeži su u Pragu prihvatili naprednjačku ideologiju. ${ }^{113}$ Koncem listopada 1908. B. G. Angjelinović se pojavio kao predsjednik Hrvatske akademske omladine Splita, koja je Mili Starčeviću poslala novac za potrebe osnutka Narodnog vijeća, ${ }^{114}$ nadstranačke organizacije u kojoj bi participirale i srpske stranke, a koja bi se zalagala za pripajanje Bosne i Hercegovine banskoj Hrvatskoj. ${ }^{115} \mathrm{Tu}$ je akciju Starčevićanska akademska mladost "najoštrije" osudila. ${ }^{116}$

Egzodus studenata sa Zagrebačkog sveučilišta i na drugi je način ugrozio mladohrvatski pokret. Osim što je Mlada Hrvatska zbog odlaska svih članova redakcije iz Zagreba prestala izlaziti, ${ }^{117}$ odlaskom vodstva Starčevićanske akademske mladosti iz Zagreba raskinuta je i veza starčevićanskih studenata sa srednjoškolcima. Starčevićanske srednjoškolske organizacije su prosvjedovale zbog prestanka izlaženja Mlade Hrvatske, tvrdeći da je zbog toga starčevićanska ideja na srednjim školama počela gubiti simpatizere. Kao odgovor na to, starčevićanska srednjoškolska mladost je prvo odlučila pokrenuti vlastiti list,,118 a zatim je u kolovozu 1908. u Zagrebu organizirala Prvi starčevićanski srednjoškolski sastanak, kojem je bio cilj stvoriti jedinstveno tijelo svih starčevićanskih srednjoškolskih organizacija. ${ }^{119}$

Na tom je sastanku ustrojen Savez organizacija Starčevićanske srednjoškolske mladosti. Prema pravilima ovog Saveza, organizacije Starčevićanske srednjoškolske mladosti stupile su u Savez organizacija Starčevićanske srednjoškolske mladosti (SOSSM), kojemu se na čelu nalazio središnji odbor Saveza koji su činili predsjednik, tajnik i blagajnik. Prema pravilima, organizacije Starčevićanske srednjoškolske mladosti okupljale su se i po hrvatskim pokrajinama: banskoj Hrvatskoj, Dalmaciji, Bosni i Hercegovini i "eventualno" Istri, gdje su im se na čelu nalazili pododbori središnjeg odbora SOSSM-a, a koji su bili posredni organi između organizacija Starčevićanske srednjoškolske mladosti te središnjeg odbora SOSSM-a. Ovom Savezu je "drug u radu" bila Starčevićanska akademska mladost, s kojom je sačinjavala

\footnotetext{
112 Priposlano. Posliednji fragment, Hrvatsko pravo, br. 3886, 31. listopada 1908.

113 Zagrebačko emigrantsko pitanje, Luč, god. 4, br. 1, rujan 1908., str. 7.

114 Temelj Narodnomu vieću, Hrvatska sloboda, br. 151, 26. listopada 1908.

115 Peršić, Kroničarski spisi, str. 178.

116 Djačke vijesti, Mlada Hrvatska, god. 2, br. 5, ožujak 1909., str. 148-149.

117 Domaće viesti, Hrvatsko pravo, br. 3740, 6. svibnja 1908.

118 Apel starčevićanskoj srednjoškolskoj mladosti, Hrvatsko pravo, br. 3760, 30. svibnja 1908.

119 Apel na starčevićanske rodoljube, Hrvatsko pravo, br. 3818, 10. kolovoza 1908.
} 
Mislav Gabelica: Mladohrvatski pokret do odvajanja od Starčevićeve hrvatske stranke prava... Zb. Odsjeka povij. znan. Zavoda povij. druš. znan. Hrvat. akad. znan. umjet., 34 (2016), str. 213-238

Starčevićansku mladost. ${ }^{120}$ Prvim predsjednikom središnjeg odbora SOSSM-a postao je Rude Štagljar-Majevčanin. ${ }^{121}$

Na svom prvom sastanku Starčevićanska srednjoškolska mladost je zaključila i stupiti u vezu sa Starčevićanskom akademskom mladosti radi obnove zajedničkog glasila Mlada Hrvatska, u koji bi se uvela rubrika za srednjoškolce i u čijem bi uredništvu bio zastupan i jedan srednjoškolac. ${ }^{122}$ Povratkom studenata u Zagreb, koncem listopada 1908., održana je glavna skupština SAM-a, na kojoj je izabran njen novi upravni odbor koji su činili predsjednik Ivan Pavičić, potpredsjednik Fran Galović, tajnici Ivo Mikinac i Josip Koprivčević, blagajnici Josip Vedral i Grga Hećimović, te odbornici Krešimir Kovačić, Ilija Maričić, Ivo Matica i Mato Mintas. ${ }^{123}$ Na skupštini se raspravljalo i o obnovi Mlade Hrvatske, te je odlučeno da će Mlada Hrvatska od sljedećeg mjeseca ponovo početi izlaziti. ${ }^{124}$ Rude Štagljar je ušao u urednički odbor obnovljene Mlade Hrvatske, u kojem su se uz njega nalazili i Fran Galović, Ivan Pavičić, Krešimir Kovačić te Ivo Mikinac.

\section{Mladohrvatski pokret u školskoj godini 1908./1909.}

Mada je na prvom sastanku starčevićanske srednjoškolske mladosti izražena bezuvjetna lojalnost te mladeži Starčevićevoj hrvatskoj stranci prava i njenom predsjedniku Josipu Franku, ${ }^{125}$ u pravila SOSSM-a je unesena odredba prema kojoj je Savez bio "sastavni dio Starčevićeve hrvatske stranke prava", uz ogradu da u stvarima unutrašnjeg poslovanja, te u izdavanju i uređivanju svog lista "pridržava potpunu autonomiju" ${ }^{126}$ Proglašenu autonomiju starčevićanska mladež je koristila za žestoke sukobe s katoličkom mladeži, što je već u siječnju 1909. rezultiralo intervencijom vodstva Starčevićeve hrvatske stranke prava u pisanje Mlade Hrvatske. ${ }^{127}$ Ova je intervencija izazvala odgovor starčevićanske mladeži, da mada "naša", Starčevićeva hrvatska stranka prava nema pravo priječiti svoju mladež u njenom autonomnom djelokrugu, odnosno u njenom "kulturnom polju rada". ${ }^{28}$

Ovakva je reakcija starčevićanske mladeži bila uvjetovana uvjerenjem dijela njenog vodstva, da pred hrvatskom mladeži predstoji "velika kulturna borba, u kojoj će sve političke grupe na univerzi postati suvišne i posve nestati". U toj borbi koja će se voditi između nositelja liberalnih i katoličkih načela, starčevićanska mladež

\footnotetext{
120 Pravila Organizacije Starčevićanske srednjoškolske mladosti, Zagreb 1909., str. 3-25. O složenom načinu izbora pokrajinskih pododbora SOSSM-a, te o organizacijama SSM-a u Bosni i Hercegovini, vidi: Iz korespodencije dr. Mile Budaka (1907.-1944.), prir. Tomislav Jonjić - Stjepan Matković, Zagreb 2012., str. 205-207, 207-208

${ }^{121}$ Srednjoškolski vijesnik, Mlada Hrvatska, god. 2, br. 8, lipanj 1909., str. 236.

122 Prvi starčevićanski srednjoškolski sastanak, Hrvatsko pravo, br. 3833, 29. kolovoza 1908.

${ }^{123}$ Domaće viesti, Hrvatsko pravo, br. 3880, 24. listopada 1908.

${ }^{124}$ Domaće viesti, Hrvatsko pravo, br. 3874, 17. listopada 1908.

${ }_{125}$ Prvi starčevićanski srednjoškolski sastanak, Hrvatsko pravo, br. 3832, 28. kolovoza 1908.

126 Pravila Organizacije Starčevićanske srednjoškolske mladosti, str. 20.

127 Čestitanja kod predsjednika stranke, Hrvatsko pravo, br. 3936, 2. siječnja 1909.

${ }^{128}$ Neka se bistri!, Mlada Hrvatska, god. 2, br. 5, ožujak 1909., str. 134-136.
} 
Mislav Gabelica: Mladohrvatski pokret do odvajanja od Starčevićeve hrvatske stranke prava... Zb. Odsjeka povij. znan. Zavoda povij. druš. znan. Hrvat. akad. znan. umjet., 34 (2016), str. 213-238

se prema zamisli svoga vodstva trebala boriti na strani liberalne Napredne omladine, koja bi se prethodno odvojila od Hrvatske pučke napredne stranke i napustila "slavosrpsku politiku", te bi postala prava "slobodoumna nepolitička grupa na univerzi". ${ }^{129}$ Pritom se prema zamisli dijela svoga vodstva i starčevićanska mladež trebala odvojiti od svoje matične stranke, no zadržala bi svoja nacionalno-politička načela, ${ }^{130}$ te bi kao hrvatska nacionalistička i liberalna omladina "regenerirala čitavo djačtvo hrvatsko", koje bi okupila pod svojim okriljem. ${ }^{131}$

Težnja za emancipacijom dijela starčevićanske mladeži od Starčevićeve hrvatske stranke prava imala je svoj odraz i u različitim poimanjima hrvatske političke zbilje, što se konkretno ticalo odnosa prema vrhbosanskom nadbiskupu Josipu Stadleru. Do aneksije Bosne i Hercegovine Starčevićeva hrvatska stranka prava je u nastojanju da privuče bosansko-hercegovačke muslimane hrvatskoj nacionalno-političkoj ideji kritizirala Stadlerovu crkveno-političku djelatnost, podupirući u Bosni i Hercegovini franjevačko svećenstvo i struju hrvatske liberalne inteligencije pod vodstvom Nikole Mandića. ${ }^{132}$ Uoči aneksije Bosne i Hercegovine, struja bosansko-hercegovačkih Hrvata pod vodstvom Nikole Mandića počela se približavati Hrvatsko-srpskoj koaliciji, napuštajući pravaški program sjedinjenja Bosne i Hercegovine s Hrvatskom. Budući da je struja pod vodstvom Josipa Stadlera zadržala taj program, ${ }^{133}$ koncem 1908. godine uspostavljeno je savezništvo Starčevićeve hrvatske stranke prava s tom strujom bosansko-hercegovačkih Hrvata. ${ }^{134}$

Unatoč tomu što je bila svjesna priklanjanja Nikole Mandića Hrvatsko-srpskoj koaliciji, ${ }^{135}$ te unatoč tomu što je držala da struja bosansko-hercegovačkih Hrvata pod vodstvom nadbiskupa Stadlera jedina "zastupa dostojno naša starčevićanska načela", starčevićanska mladež nije slijedila taktiku svoje matične stranke, te nije podržala nadbiskupa Stadlera, i dalje ga smatrajući "velikom nesrećom" po hrvatske nacionalne interese u Bosni i Hercegovini zbog njegovih "klerikalnih" načela. ${ }^{136}$ Starčevićanska mladež je smatrala da je Starčevićeva hrvatska stranka prava "učinila jednu taktičku pogrješku, kada se je postavila na stranu dra. Stadlera", te je pozvala i Stadlera i Mandića da se povuku iz vodstva svojih organizacija i da vodstvo nad bosansko-hercegovačkim Hrvatima prepuste navodno nekompromitiranom Josipu Sunariću. ${ }^{137}$

\footnotetext{
${ }^{129}$ Krešimir Kovačić, Kulturna borba na hrvatskoj univerzi, Mlada Hrvatska, god. 2, br. 6/7, travanj 1909., str. 164-165.

130 Prilike djaštva na hrvatskoj univerzi, Mlada Hrvatska, god. 2, br. 9/10, str. 241-244.

${ }_{131}$ Rude Štagljar, Nove borbe. K 2. sastanku starčevićanskog srednjoškolskog djaštva u Zagrebu 27. i 28. kolovoza 1909., Mlada Hrvatska, god. 2, br. 9/10, str. 246-248.

132 Matković, Čista stranka prava, str. 119-122.

133 Gross, Hrvatska politika u Bosni i Hercegovini, str. 30-32, 38-43.

${ }^{134}$ Deputacija Hrvata katolika iz Bosne i Hercegovine u Zagrebu, Hrvatsko pravo, 28. studenoga 1908. Klubovima i svim pristašama Starčevićeve hrvatske stranke prava, Hrvatsko pravo, 11. prosinca 1908.

135 Politika, Mlada Hrvatska, god. 2, br. 3, siječanj 1909., str. 88.

136 Politika, Mlada Hrvatska, god. 2, br. 5, ožujak 1909., str. 153.

137 Politika, Mlada Hrvatska, god. 2, br. 6/7, travanj 1909., str. 201.
} 
Mislav Gabelica: Mladohrvatski pokret do odvajanja od Starčevićeve hrvatske stranke prava... Zb. Odsjeka povij. znan. Zavoda povij. druš. znan. Hrvat. akad. znan. umjet., 34 (2016), str. 213-238

Težnja dijela starčevićanskog đaštva da se emancipira od Starčevićeve hrvatske stranke prava nije prošlo bez reakcije onih, koji se s tim nisu slagali. Na inicijativu tih čimbenika, polovicom 1909. godine je izvršena reorganizacija Starčevićanske akademske mladosti, koja je od samostalne organizacije postala "akademski klub", koji je trebao postati "dio jedinstvene organizacije starčevićanske mladosti, u kojoj će biti zastupani i akademičari i srednjoškolci i radnici i trgovačka mladost, te napokon sva ostala mladja inteligencija, koja je svršila univerzu". Ta je jedinstvena organizacija trebala biti "čvrst oslon našoj Starčevićevoj hrvatskoj stranci prava". ${ }^{138}$ Starčevićanski akademski klub dobio je naziv Kumičić, a njegovim su članovima osim aktivnih studenata mogli postati i svršeni studenti, odnosno "seniori". U prvom upravnom odboru Kumičića, izabranom za ljetni semestar školske godine 1908./1909., predsjednik je bio Ivan Pavičić, potpredsjednik Fran Galović, tajnik Grgo Novak, blagajnik Josip Vedral, a odbornici Zvonimir Milković, Krešimir Kovačić, Ivan Matica, Grga Hećimović, Ivo Mikinac i Ilija Maričić. ${ }^{139}$

Osnutkom Kumičića, Starčevićanska akademska mladost prestala je postojati kao organizacija, zbog čega više nije biran njen upravni odbor. U ime "starčevićanske akademske mladosti" sada je istupao upravni odbor Kumičića ${ }^{140}$ Prema shvaćanju onih koji su se slagali s osnutkom Kumičića, "starčevićanska akademska mladost" je nakon osnutka kluba Kumičić postala grupa studenata, političkih istomišljenika, koji se organiziraju u klubu Kumičić. ${ }^{141}$ Međutim, prema shvaćanju onih koji se nisu slagali s osnutkom Kumičića i koji su težili emancipaciji starčevićanske mladeži od Starčevićeve hrvatske stranke prava, osnutkom tog kluba Starčevićanska akademska mladost nije prestala postojati kao organizacija, nego je Kumičić osnovan u njenom "okviru", ${ }^{142}$ isključivo kao "kulturni klub, koji nikako ne može reprezentirati starčevićansku akademsku mladost". ${ }^{143}$

Težnja za stvaranjem đačke organizacije, koja bi bila liberalna i koja bi počivala na pravaškim načelima, ali bi bila neovisna od Starčevićeve hrvatske stranke prava kako bi okupila i Naprednu omladinu, bila je osobito prisutna u radu starčevićanske srednjoškolske mladeži. Na konferenciji starčevićanskih srednjoškolskih organizacija iz banske Hrvatske, održanoj u travnju 1909., predsjednik SOSSM-a Rude Štagljar je kao jedan od najvećih uspjeh Saveza u protekloj godini istaknuo "to što smo raščistili naše stajalište prema klerikalizmu i doveli do pobjede u našim redovima pravi liberalizam". U tom smislu je donesena i rezolucija, kojom se odobrilo pisanje Mlade Hroatske, a "napose istup proti i onako nestarčevićanskih klerikalaca". ${ }^{144} \mathrm{Na}$ Drugom sastanku starčevićanske srednjoškolske mladosti, održanom u kolovozu 1909.,

${ }^{138}$ Djačke vijesti, Mlada Hrvatska, god. 2, br. 8, lipanj 1909., str. 230.

139 Djačke vijesti, Mlada Hrvatska, god. 2, br. 9/10, str. 282-283.

${ }^{140}$ Izjava starčevićanske akademske mladosti, Hrvatsko pravo, br. 4258, 31. siječnja 1910.

${ }^{141}$ Domaće viesti, Hrvatsko pravo, br. 4211, 3. prosinca 1909.; Domaće viesti, Hrvatsko pravo, br. 4287, 7. ožujka 1910.

${ }_{142}$ Djačke vijesti, Mlada Hrvatska, god. 3, br. 1/2, listopad-studeni 1909., str. 36.

${ }_{143}$ Djačke vijesti, Grabancijaš, god. 1, br. 1, Zagreb, ožujak 1910., str. 23.

${ }_{144}$ Srednjoškolski vijesnik, Mlada Hrvatska, god. 2, br. 8, lipanj 1909., str. 236-237. 
Mislav Gabelica: Mladohrvatski pokret do odvajanja od Starčevićeve hrvatske stranke prava... Zb. Odsjeka povij. znan. Zavoda povij. druš. znan. Hrvat. akad. znan. umjet., 34 (2016), str. 213-238

prihvaćena je rezolucija prema kojoj se starčevićanske srednjoškolske organizacije "u političkom smislu" potpuno identificiraju sa Starčevićevom hrvatskom strankom prava, ali da "u djačkim stvarima, kao npr. u pitanju Mlade Hrvatske ili odnošaja prema ostalim djačkim grupama", zadržavaju "potpunu slobodu, smatrajuć se organizacijom od same stranke potpuno neovisnom". ${ }^{145}$

\section{Mladohrvatski pokret u školskoj godini 1909./1910.}

Početkom nove školske godine, među starčevićanskom sveučilišnom mladeži dominirala je struja, koja se željela emancipirati od Starčevićeve hrvatske stranke prava i surađivati s Naprednom omladinom. U to je vrijeme predsjednik upravnog odbora Kumičića bio Grgo Novak, tajnik je bio Marko Kožul, a blagajnik Bariša Smoljan. Glavni urednik Mlade Hrvatske bio je Krešimir Kovačić, a članovi uredništva bili su Augustin Ujević, Zvonimir Milković, Grgo Novak, Marko Kožul i Bariša Smoljan. ${ }^{146}$ Uoči izbora za upravni odbor HAPD-a, "Starčevićanska akademska mladost" sklopila je izborni sporazum s Naprednom omladinom i milinovskom Organizacijom starčevićanskih akademičara, te je njihova lista pobijedila samostalnu listu grupe oko Domagoja. ${ }^{147}$ Od pristaša starčevićanske sveučilišne mladeži u mješoviti su odbor HAPD-a izabrani Grgo Novak, Krešimir Kovačić, Ivo Čvoriščec, Nikola Rukavina i Jure Šutej. ${ }^{148}$ Istovremeno su se na stranicama Mlade Hrvatske počeli pojavljivati dotadašnji pripadnici Napredne omladine: Karlo Häusler, Ljubo Wiesner, te Janko Polić Kamov.

Suradnja dijela starčevićanske sveučilišne mladeži s Naprednom omladinom izazvala je reakciju drugog dijela te mladeži, koja se oglašavala posredstvom Hrvatskog prava. U tom su listu u listopadu 1909. počeli izlaziti članci anonimnog starčevićanskog studenta, upereni protiv suradnje starčevićanske mladeži s Naprednom omladinom, na koje je "Starčevićanska akademska mladost" reagirala izjavom, kojom su ti članci osuđeni. ${ }^{149}$ Ubrzo potom, u prosincu su na zagrebačkom Sveučilištu održane demonstracije "hrvatske akademičke mladosti", koja je prosvjedovala protiv podrške, koju je Napredna omladina javno odaslala Franu Supilu tijekom Friedjungove parnice. Među govornicima na prosvjedu se nije nalazio nitko iz čelništva Kumičića, niti itko iz uredništva Mlade Hrvatske. ${ }^{150}$ Nakon tih demonstracija Napredna omladina se na stranicama Hrvatskog prava počela nazivati "pokretaškom fukarom". ${ }^{151}$

U isto je vrijeme zastupnik Starčevićeve hrvatske stranke prava, svećenik Ivan Nepomuk Jemeršić objavio članak u katoličkoj Luči, u kojem je osudio protukatoličko,

\footnotetext{
145 Štagljar, Starčevićansko djaštvo na svom drugom sastanku, Mlada Hrvatska, god. 3, br. 3, prosinac 1909., str. 70-72.

146 Djačke vijesti, Mlada Hrvatska, god. 3, br. 1/2, listopad/studeni 1909., str. 36.

147 Luetić, Studenti Sveučilišta u Zagrebu, str. 353, 391.

148 Iz djačkoga života, Hrvatski djak, god. 4, br. 2, studeni 1909., str. 51-53.

149 Domaće viesti, Hrvatsko pravo, br. 4184, 2. studenoga 1909.

150 Manifestacija hrvatskih akademičara, Hrvatsko pravo, br. 4223, 17. prosinca 1909.

151 Domaće viesti, Hrvatsko pravo, br. 4226, 21. prosinca 1909.
} 
Mislav Gabelica: Mladohrvatski pokret do odvajanja od Starčevićeve hrvatske stranke prava... Zb. Odsjeka povij. znan. Zavoda povij. druš. znan. Hrvat. akad. znan. umjet., 34 (2016), str. 213-238

nemoralno pisanje Mlade Hrvatske, te je poželio da starčevićanska mladež krene "boljim putem", odnosno da u Domagoju i Marijinim kongregacijama "ne gleda protivnike svojih domovinskih i zdravih političko-kulturnih težnji i nastojanja", nego da se oko Luči okupi "sva katolička mladež u Hrvatskoj", a da se oko Mlade Hrvatske okupi "starčevićanska mladež" svih konfesija, te da Luč i Mlada Hrvatska "zajedno žive međusobno u čistoj ljubavi, kao dvije mlade i bujne grane na starom stablu hrvatstva". ${ }^{152}$

Reakcija čimbenika koji su se protivili emancipaciji starčevićanske mladeži od njene matične stranke i njenoj suradnji s Naprednom omladinom, izazvala je prekid suradnje trideset sedmorice dotadašnjih suradnika i pristaša Mlade Hrvatske s tim listom, "budući da nam se hoće nametnuti smjer, koji ne odgovara osnutku i svrsi Mlade Hrvatske". Od članova uredništva Mlade Hrvatske, čelništva Kumičića i starčevićanskih članova HAPD-a, izjavu o prekidu suradnje potpisali su Marko Kožul, Krešimir Kovačić, Augustin Ujević i Zvonimir Milković. Od znamenitijih pripadnika starčevićanske mladeži potpisali su je i Rude Štagljar, Musa Ćazim-Ćatić, Fran Galović, Fadil Kutragić i Džaferbeg Kulenović. ${ }^{153}$ Neki od potpisanih, kao primjerice Fadil Kurtagić, kasnije su javno izjavili da su potpisani bez svog znanja, a dio je potpisanih, kao primjerice Fran Galović, bez javnog demantija nastavio surađivati s Mladom Hrvatskom. Disidenti su u veljači 1910. na Sveučilištu osnovali organizaciju i prozvali se Starčevićanski slobodoumni akademičari, ${ }^{154}$ odnosno Starčevićansko slobodoumno djaštvo. Prema tvrdnji akademičara koji su ostali uz Mladu Hrvat$s k u$, ova je organizacija brojila samo pet članova. ${ }^{155}$ Prema kasnijoj tvrdnji, disidenata je bilo šest. ${ }^{156}$ Među njima su se nedvojbeno nalazili Krešimir Kovačić, Tin Ujević i Rude Štagljar.

Naprednjački je tisak smatrao da je raskol među starčevićanskom mladeži uzrokovao pritisak iz vodstva Starčevićeve hrvatske stranke prava, koje je navodno izdalo naredbu da Mlada Hrvatska mora pisati u čisto stranačkom i klerikalnom duhu, "inače da stranka neće snositi troškove lista". ${ }^{157}$ Međutim, Starčevićeva hrvatska stranka prava se nije otvoreno opredijelila protiv disidenata, nego je Hrvatsko pravo objavljivalo sve njihove izjave i proglase, kao što je bila najava izlaženja lista Grabancijaš, ${ }^{158}$ te je kritizirala preoštre napade na disidente sa strane njihovih bivših kolega, zauzimajući stajalište da je spor unutar redova starčevićanske mladeži isključivo "radi književnih smjerova" i nadajući se da će se mladež vremenom opet složiti. ${ }^{159}$

\footnotetext{
${ }^{152}$ Ivan Nepomuk Jemeršić, Moj odgovor Luči i savjeti našoj dičnoj katoličkoj u obće a napose i starčevićanskoj mladeži oko Mlade Hrvatske, Luč, god. 5, br. 4, siječanj 1910.

153 Izjava, Hrvatsko pravo, br. 4256, 28. siječnja 1910;; Domaće vijesti, Hrvatsko pravo, br. 4257, 29. siječnja 1910.

154 Svaštice, Luč, god. 5, br. 5, veljača 1910., str. 255.

${ }_{155}$ Ivan Pavičić, Da se razumijemo!, Hrvatsko pravo, br. 4292, 12. ožujka 1910.

156 Djačka kronika, Mlada Hrvatska, god. 3, br. 7, travanj 1910., str. 206.

157 Raskol počinje, Male novine, br. 7, Zagreb, 29. siječnja 1910.

${ }_{158}$ Domaće viesti, Hrvatsko pravo, br. 4290, 10. ožujka 1910.

159 Domaće viesti, Hrvatsko pravo, br. 4296, 17. ožujka 1910.
} 
Mislav Gabelica: Mladohrvatski pokret do odvajanja od Starčevićeve hrvatske stranke prava... Zb. Odsjeka povij. znan. Zavoda povij. druš. znan. Hrvat. akad. znan. umjet., 34 (2016), str. 213-238

Starčevićanska mladež koja je ostala uz Mladu Hrvatsku, čin disidenata oštro je osudila. Fadil Kurtagić, kojem je "politička strana našeg programa" bila važnija od "kojekakvih svakidanjih kulturnih natezanja", smatrao je da je "našim disidentima" pod utjecajem Antuna Gustava Matoša ${ }^{160}$ pred očima vremenom "blijedio politički moment" "pred kojekakvim kulturnim smicalicama". Odraz toga je bilo, prema Kurtagiću, uvlačenje naprednjaka u Mladu Hrvatsku. Kurtagić je smatrao da su vođe disidenata, Krešimir Kovačić i Rude Štagljar, kao slabi karakteri naposljetku kapitulirali pred naprednjacima i prihvatili njihovu ideologiju. ${ }^{161} \mathrm{Na}$ tvrdnje disidenata da je raskol starčevićanske mladeži uzrokovala "klerikalna" struja unutar te mladeži, Mlada Hrvatska je pisala da je raskol uzrokovalo upozorenje iz redova starčevićanske mladeži upućeno tadašnjem uredništvu lista, "da malo više pripaze na pravu svrhu glasila i da se otresu koketiranja s naprednim djaštvom". Za starčevićansku mladež je bilo jasno da je organizacija Starčevićanskog slobodoumnog djaštva samo međufaza na putu potpune preobrazbe starčevićanskih disidenata u naprednjake. ${ }^{162}$

Ubrzo po raskolu među starčevićanskom mladeži, izabran je novi upravni odbor akademskog kluba Kumičić, ${ }^{163}$ koji je u obraćanju javnosti naveo da ne želi hiniti neovisnost, kao što to hini Napredna omladina u odnosu na Hrvatsku pučku naprednu stranku, nego da želi čvrst savez sa Starčevićevom hrvatskom strankom prava, kako bi pripadnici starčevićanske mladeži kao svršeni studenti postali “dostojni zamjenici naših prvaka u započetom radu na ostvarenju ideala - programa Ante Starčevića" ${ }^{164}$

Disidenti su svoje stanovište o odnosu prema Starčevićevoj hrvatskoj stranci prava iznijeli u ožujku 1910., u prvom i jedinom broju svog lista Grabancijaš. ${ }^{165} \mathrm{U}$ tom se listu u prvom redu načelno tražilo da se studenti odvoje od političkih stranaka. ${ }^{166}$ Mada je hrvatska nacionalna ideja proglašena "najrealnijim, najbližim i najstvarnijim našim idealom", njegovim najvećim protivnikom nije proglašena ni jugoslavenska

\footnotetext{
${ }^{160}$ Mirjana Gross navodi da su autori članaka u Mladoj Hrvatskoj već od prvog broja toga lista, dakle od siječnja 1908. "razrađivali Matoševe osnovne koncepcije", što argumentira Anđelinovićevim člankom objavljenim u tom broju, gdje Anđelinović između ostaloga piše o potrebi ne samo borbe protiv jugoslavenske političke ideje, nego i borbe protiv "shvaćanja o kulturnom jedinstvu Južnih Slavena, koje dosljedno zahtijeva i političko jedinstvo". Zbog toga je Anđelinović tražio razvoj "originalne" hrvatske kulture. Gross, Nacionalne ideje studentske omladine, str. 85. Međutim, na drugom mjestu Mirjana Gross analizira Matoševa stajališta, iz kojih se vidi da je Matoš doduše odbacivao ideju jugoslavenskog političkog jedinstva, ali da je hrvatsku kulturu smatrao dijelom slavenske kulture, kojoj su "naročito blizanačke" bile slovenska i srpska kultura, zbog čega je Matoš tražio "kulturno zbliženje i kulturnu zajednicu Južnih Slavena". Gross, Nacionalne ideje studentske omladine, str. 100-101. Navedeno Anđelinovićevo i Matoševo stajalište o hrvatskoj kulturi su različita, pa se na temelju njih teško može zaključiti, da su mladohrvati od početka "razrađivali Matoševe osnovne koncepcije".

${ }^{161}$ Fadil Kurtagić, Ambiciozni intermezzo, Mlada Hrvatska, god. 3, br. 4/5, siječanj/veljača 1910., str. 85-87.

${ }_{162}$ Djačka kronika, Mlada Hrvatska, god. 3, br. 4/5, siječanj/veljača 1910., str. 109.

${ }_{163}$ Djačka kronika, Mlada Hrvatska, god. 3, br. 6, ožujak 1910., str. 162.

${ }_{164}$ Sa Kumičićeve skupštine, Hrvatsko pravo, br. 4297, 18. ožujka 1910.

${ }^{165}$ O stajališstima iznesenima u tom listu vidi: Gross, Nacionalne ideje studentske omladine, str. 91-92.

166 Rakovim korakom, Grabancijaš - glasilo starčevićanskog slobodoumnog đaštva, br. 1, Zagreb, ožujak 1910., str. 1-2.
} 
Mislav Gabelica: Mladohrvatski pokret do odvajanja od Starčevićeve hrvatske stranke prava... Zb. Odsjeka povij. znan. Zavoda povij. druš. znan. Hrvat. akad. znan. umjet., 34 (2016), str. 213-238

ni velikosrpska ideja, nego "klerikalzam", koji da se uvlači u redove hrvatskih nacionalista, odnosno u Starčevićevu hrvatsku stranku prava. Osim zbog toga, ova je stranka kritizirana i zbog "popuštanja taktikama”, "kompromisa”, "tajanstvenosti u radu", umjesto čega je ova mladež isticala svoj "radikalni idealizam". ${ }^{167}$

Iako je navela da od svih stranaka "imade jedino povjerenje u Starčevićevu hrvatsku stranku prava", 168 ova je mladež za razliku od te stranke, ali i za razliku od mladeži koja se okupljala oko Mlade Hrvatske, u sporu među bosansko-hercegovačkim Hrvatima katolicima izričito stavila na stranu Nikole Mandića i Hrvatske narodne zajednice. ${ }^{169}$ Prema mišljenju mladeži koja je ostala uz Mladu Hrvatsku, pozitivno stajalište disidenata prema Nikoli Mandiću, koji da je "u neposrednoj vezi" s Hrvatskosrpskom koalicijom, te Hrvatskoj narodnoj zajednici, koja da "otvoreno napada našeg predsjednika" Josipa Franka, bio je najbolji pokazatelj stvarnog odnosa ove mladeži prema Starčevićevoj hrvatskoj stranci prava. ${ }^{170}$ Prema istom izvoru, razlog zašto je grupa oko Grabancijaša izricala simpatije za Starčevićevu hrvatsku stranku prava bio je u njihovom pokušaju privlačenja starčevićanskih srednjoškolaca. ${ }^{171}$

Starčevićansko slobodoumno djaštvo imalo je namjeru postati organizacija koja će kao "neovisna nacionalistička djačka grupa" okupiti studente i srednjoškolce. ${ }^{172}$ Već neposredno nakon raskola, akademski klub Kumičić je u ime starčevićanske akademske mladosti pozvao starčevićanske studente sa Sveučilišta u Beču, te starčevićanske srednjoškolce da ostanu mirni. ${ }^{173}$ Ubrzo potom, novostvoreni "odbor hrvatskog starčevićanskog slobodoumnog djaštva" razaslao je okružnice starčevićanskim srednjoškolskim organizacijama, u kojima ih je pozvao da se odcijepe od kluba Kumičić i pristupe njima. Ove su to u ožujku 1910. odbile, solidarizirajući se sa stajalištem središnjeg odbora SOSSM-a. ${ }^{174}$ Disidente su u isto vrijeme osudili i starčevićanski sveučilištarci s bečkog Sveučilišta, okupljeni u društvu Mlada Hrvatska. ${ }^{175}$

Međutim, starčevićanski srednjoškolci, među kojima se u ovo vrijeme počinje isticati maturant Mile Budak, počeli su se neovisno od grupe oko Grabancijaša emancipirati od akademskog kluba Kumičić te Starčevićeve hrvatske stranke prava, koja je početkom 1910. godine posredstvom vrhbosanskog nadbiskupa Stadlera povela pregovore s kršćansko-socijalnom grupom oko lista Hrvatstvo o fuziji. ${ }^{176} \mathrm{U}$ ožujku 1910., u apelu starčevićanskim srednjoškolcima da se ne odazovu pozivu grupe oko Grabancijaša, senior akademskog kluba Kumičić Ivan Pavičić je naveo da se nada da

167 Štagljar, Novi duh, Grabancijaš, br. 1, ožujak 1910., str. 8-10.

168 Djačke vijesti, Grabancijaš, br. 1, ožujak 1910., str. 22.

169 Štagljar, Narodna obrana, Grabancijaš, br. 1, ožujak 1910., str. 29-30.

170 Da se razumijemo, Hrvatsko pravo, br. 4292, 12. ožujka 1910.

${ }_{171}$ Djačka kronika, Mlada Hrvatska, god. 3, br. 7, travanj 1910., str. 206.

172 Djačke vijesti, Grabancijaš, god. 1, br. 1, ožujak 1910., str. 22-23.

${ }^{173}$ Izjava starčevićanske akademske mladosti, Hrvatsko pravo, br. 4258, 31. siječnja 1910.

174 Srednjoškolski vijesnik, Mlada Hrvatska, god. 3, br. 6, ožujak 1910., str. 178.

${ }_{175}$ Dopisi, Mlada Hrvatska, god. 3, br. 6, ožujak 1910., str. 166-167.

176 Iso Kršnjavi, Zapisci. Iza kulisa hrvatske politike, knjiga druga, Zagreb 1986., str. 616; O razlozima za pokretanje tih pregovora i o fuziji vidi: Matković, Stranka prava i hrvatski kršćanski socijali, u: Hrvatski katolički pokret, str. 321-330. 
Mislav Gabelica: Mladohrvatski pokret do odvajanja od Starčevićeve hrvatske stranke prava... Zb. Odsjeka povij. znan. Zavoda povij. druš. znan. Hrvat. akad. znan. umjet., 34 (2016), str. 213-238

će se "razmirice izmedju akademičara i srednjoškolaca glede Mlade Hrvatske ubrzo i složno urediti na korist i zadovoljstvo sviju". ${ }^{177}$

U svibnju 1910. u Sarajevu je održana sjednica bosansko-hercegovačkog pododbora SOSSM-a, kojoj je prisustvovao i predsjednik Saveza Josip J. Mihajlov. Na sastanku je zaključeno da SOSSM treba povući "skrajnje konzekvence" ako se ne udovolji njegovim zahtjevima, koji da su već u studenom 1909. bili uručeni egzekutivnom odboru Starčevićeve hrvatske stranke prava. Zahtjevi bosansko-hercegovačke srednjoškolske mladeži su se, čini se, odnosili na nezadovoljstvo što se Starčevićeva hrvatska stranka prava u sporu među bosansko-hercegovačkim Hrvatima opredijelila za nadbiskupa Stadlera, dok je njihovo stajalište i dalje bilo da nadbiskup Stadler i Nikola Mandić predstavljaju jednako zlo po hrvatske interese. ${ }^{178}$ Budući da su tekstovi pisani u tom duhu o toj dvojici hrvatskih prvaka u Bosni i Hercegovini bili objavljivani u Mladoj Hrvatskoj i nakon što je akademski klub Kumičić "prestao hiniti neovisnost od Starčevićeve hrvatske stranke prava", 179 jasno je da je u siječnju 1910. odstupom starog uredništva, uređivanje lista došlo u ruke srednjoškolskoj mladeži, što je izazvalo spomenuti spor s akademskom mladeži.

U takvoj je atmosferi u kolovozu 1910. organiziran treći sastanak starčevićanske srednjoškolske mladosti, koji je održan uoči konačne fuzije Starčevićeve hrvatske stranke prava s kršćansko-socijalnom grupom oko lista Hrvatstvo. Na tom su se sastanku starčevićanski srednjoškolci usprotivili fuziji, zbog čega su se odvojili i od svoje stranke i od starčevićanskih studenata okupljenih u klubu Kumičić. U tomu ih je podržalo starčevićansko akademsko društvo sa Sveučilišta u Beču, Mlada Hrvatska. Savez organizacija starčevićanske srednjoškolske mladosti (SOSSM) je prihvatio novi, tzv. mladohrvatski program, te se transformirao u "Savez organizacija mladohrvatskog starčevićanskog đaštva", u koji je osim starčevićanskih srednjoškolskih organizacija ušlo i starčevićansko akademsko društvo sa Sveučilišta u Beču, Mlada Hrvatska. Najavljeno je da će se iduće školske godine i na zagrebačkom Sveučilištu osnovati akademsko društvo, koje će stupiti u Savez mladohrvatskih organizacija. Predsjednikom tog Saveza postao je svršeni maturant Mile Budak. ${ }^{180}$ Transformacijom SOSSM, najviše specifično srednjoškolske mladohrvatske organizacije postali su pokrajinski pododbori starog SOSSM-a. ${ }^{181}$ Savez mladohrvatskih organizacija potpuno je prisvojio vlasništvo nad listom Mlada Hrvatska, čijim je glavnim urednikom postao Mile Budak. ${ }^{182}$

\footnotetext{
177 Ivan Pavičić, Da se razumijemo!, Hrvatsko pravo, br. 4290, 12. ožujka 1910.

178 Srednjoškolski vijesnik, Mlada Hrvatska, god. 3, br. 8/9, svibanj/lipanj 1910., str. 279.

179 Fadil Kurtagić, Političke prilike u Herceg-Bosni poslije proglašenja ustava, Mlada Hrvatska, god. 3, br. 7, travanj 1910., str. 181-182; Feuilleton, Mlada Hrvatska, god. 3, br. 8/9, svibanj/lipanj 1910., str. 272-274.

180 Politički prevrat?! Ili prvi mladohrvatski zbor u Zagrebu, 27. i 28. kolovoza 1910., Zagreb 1910.

181 Srednjoškolski vijesnik, Mlada Hrvatska, god. 4, br. 6, lipanj 1911., str. 184.

182 Mlada Hrvatska, Hrvatsko pravo, br. 4429, 29. kolovoza 1910. Životopis Mile Budaka vidi u: Tomislav Jonjić - Stjepan Matković, Dr. Mile Budak-književnik i političar, u: Iz korespondencije dr. Mile Budaka (1907.-1944.), str. 11-187.
} 
Mislav Gabelica: Mladohrvatski pokret do odvajanja od Starčevićeve hrvatske stranke prava... Zb. Odsjeka povij. znan. Zavoda povij. druš. znan. Hrvat. akad. znan. umjet., 34 (2016), str. 213-238

Akademski klub Kumičić nije se protivio fuziji svoje stranke s hrvatskim kršćanskim socijalima. Njemu su stranački krugovi namijenili da se fuzionira s akademskim društvom Domagoj. Međutim, tu je mogućnost otklonila katolička mladež. Koncem rujna 1910. predsjednik Domagoja Velimir Deželić je izvijestio da mu nije ništa poznato o glasinama da se sprema fuzija Domagoja s Kumičićem. ${ }^{183}$ Polovicom listopada iste godine predstavništvo Hrvatskog katoličkog narodnog đaštva je "u pogledu vijesti, koje su izbile na javu" objavilo izjavu, u kojoj su sve takve vijesti proglašene "posve neosnovane". ${ }^{184}$ Polovicom studenog iste godine, na glavnoj skupštini starčevićanskih studenata na zagrebačkom Sveučilištu, na kojem su sada bili i prošlogodišnji maturanti, "uklonjena je svaka opreka između organizacija sveukupnog starčevićanskog đaštva", 185 te je konstituiran nov upravni odbor Kumičića, čiji je predsjednik postao Nikola Zadro, potpredsjednik Jure Šutej, a tajnik Mile Budak. ${ }^{186}$ Time je klub Kumičić stupio u Savez mladohrvatskih organizacija, a Hrvatsko pravo, list Stranke prava nastale fuzijom Starčevićeve hrvatske stranke prava s hrvatskim kršćanskim socijalima, počeo je posve ignorirati djelovanje starčevićanske mladeži i počeo pomno pratiti djelovanje Domagoja.

\section{Zaključak}

Suština mladohrvatskog pokreta je organiziranje srednjoškolske mladeži na starčevićanskim načelima. Mladohrvatski pokret je nastao oko 1907. godine, kada je stvorena zajednička organizacija starčevićanskih srednjoškolaca i akademičara. Prethodne, 1906. godine, počele su se osnivati prve starčevićanske srednjoškolske organizacije a iduće, 1908. godine, pokrenut je list starčevićanske mladeži Mlada Hrvatska, koji je prema tvrdnji njegovih suradnika pokrenut da bude komunikacijsko sredstvo između starčevićanskih akademičara i srednjoškolaca. Pokretanjem tog lista, koji je zastupao liberalna načela, od starčevićanske mladeži se počela odvajati katolička mladež, koja se već ranije počela samostalno organizirati u sklopu Hrvatskog katoličkog pokreta.

Manji dio starčevićanske mladeži, i to uglavnom dio njenog vodstva, vremenom se počeo okretati suradnji s Naprednom omladinom i odvajati se od Starčevićeve hrvatske stranke prava, čiji je integralni dio ova mladež bila. Namjera ovog dijela starčevićanske mladeži bila je stvoriti jedinstven pokret cjelokupne hrvatske mladeži, koji bi stajao na pravaškom nacionalno-političkom, te na liberalnom stanovištu. Tomu se usprotivio veći dio starčevićanske mladeži, ali i Starčevićeva hrvatska stranka prava, čijim posredovanjem je na zagrebačkom Sveučilištu stvoren akademski klub Kumičić kao središte starčevićanske đačke mladeži, koji je bio čvrsto vezan uz stranku. Namjera Starčevićeve hrvatske stranke prava, koja je u to vrijeme povela

183 Domaće vijesti, Hrvatsko pravo, br. 4452, 26. rujna 1910.

184 Izjava, Hrvatsko pravo, br. 4466, 12. listopada 1910.

185 Đačke vijesti, Mlada Hrvatska, god. 4, br. 1, str. 20

186 Družtvene vijesti, Hrvatsko pravo, br. 4504, 26. studenoga 1910. 
Mislav Gabelica: Mladohrvatski pokret do odvajanja od Starčevićeve hrvatske stranke prava... Zb. Odsjeka povij. znan. Zavoda povij. druš. znan. Hrvat. akad. znan. umjet., 34 (2016), str. 213-238

pregovore o fuziji s hrvatskim kršćanskim socijalima, bila je fuzionirati starčevićansku i katoličku mladež. Tomu se usprotivila starčevićanska srednjoškolska mladež, koja je proglasila neovisnost od stranke. Iz organizacije starčevićanske srednjoškolske mladeži stvorena je organizacija utemeljena na tzv. mladohvatskom programu, u koju je stupilo i starčevićansko akademsko društvo sa Sveučilišta u Beču. Nakon što je društvo Domagoj odbilo fuziju s društvom Kumičić, i ta je organizacija starčevićanske mladeži stupila u Savez mladohrvatskih organizacija. 
Mislav Gabelica: Mladohrvatski pokret do odvajanja od Starčevićeve hrvatske stranke prava... Zb. Odsjeka povij. znan. Zavoda povij. druš. znan. Hrvat. akad. znan. umjet., 34 (2016), str. 213-238

Mislav Gabelica

\title{
The Young Croat Movement until Its Separation from Starčević's Party of Rights in 1910
}

\begin{abstract}
Summary
The article deals with the genesis of the Young Croat Movement, and provides an analysis of its structure, significance and activity in the first phase of its existence, that is, until its separation in 1910 from Starčević's Croatian Party of Rights, in the framework of which the movement developed till then. The basic thesis of the article is that the essence of all youth movements in Croatia at the beginning of the twentieth century, including the essence of the Young Croat Movement, should be sought in the politicisation of high school youth, aimed at connecting that youth, as early as that time, to particular political programmes. Consequently, the essence of the Young Croat Movement, which started in 1907, was the "recruiting of future soldiers" for Starčević's Croatian Party of Rights among the high school youth. The article is made on the basis of the previous results of historiography and on the basis of the analysis of archival sources, brochures, memoirs and especially texts printed in the publications of contemporary high school and university students and political parties. Particular units within the topic are ordered chronologically: one after the other, they analyse the balance of power within the University of Zagreb until the appearance of the Young Croat Movement, the appearance of rival youth movements, the appearance of the Young Croat Movement and its activity in the first years of its existence, and, finally, the state of that movement at the moment of its separation from its parent political party - that is, Starčević's Croatian Party of Rights.
\end{abstract}

Key words: Starčević's Croatian Party of Rights, students, high school youth, Young Croat Movement 